FACTA UNIVERSITATIS

Series: Mechanical Engineering Vol. 18, No 3, 2020, pp. 375 - 397

https://doi.org/10.22190/FUME200307036R

Original scientific paper

\title{
A CLOUD TOPSIS MODEL FOR GREEN SUPPLIER SELECTION
}

\section{Krishnapuram Ravi Ramakrishnan, Shankar Chakraborty}

\author{
Department of Production Engineering, Jadavpur University,
} Kolkata, West Bengal, India

\begin{abstract}
Due to stringent governmental regulations and increasing consciousness of the customers, the present day manufacturing organizations are continuously striving to engage green suppliers in their supply chain management systems. Selection of the most efficient green supplier is now not only dependant on the conventional evaluation criteria but it also includes various other sustainable parameters. This selection process has already been identified as a typical multi-criteria group decision-making task involving subjective judgments of different participating experts. In this paper, a green supplier selection problem for an automobile industry is solved while integrating the Cloud model with the technique for order of preference by similarity to an ideal solution (TOPSIS). The adopted method is capable of dealing with both fuzziness and randomness present in the human cognition process while appraising performance of the alternative green suppliers with respect to various evaluation criteria. This model identifies green supplier $S_{4}$ as the best choice. The derived ranking results using the adopted model closely match with those obtained from other variants of the TOPSIS method. The Cloud model can efficiently take into account both fuzziness and randomness in a qualitative attribute, and effectively reconstruct the qualitative attribute into the corresponding quantitative score for effective evaluation and appraisal of the considered green suppliers. Comparison of the derived ranking results with other MCDM techniques proves applicability, potentiality and solution accuracy of the Cloud TOPSIS model for the green supplier selection.
\end{abstract}

Key Words: Cloud Model, TOPSIS, Selection, Green Supplier, Rank

Received March 07, 2020 / Accepted May 23, 2020

Corresponding author: S. Chakraborty

Department of Production Engineering, Jadavpur University, Kolkata

E-mail: s_chakraborty00@yahoo.co.in 


\section{INTRODUCTION}

In today's enormous competitive environment, the aim of any manufacturing organization must be focused on satisfying its customers with low cost high quality products and prompt services, while keeping in mind their changing demands and perspectives. Thus, the production system needs to be so designed as to decrease the related manufacturing cost, increase its flexibility and meet the quality standards. As in any production system, raw materials are usually converted into finished products, any variation in the quality of the input materials may result in deterioration of the final product quality. Thus, in the supply chain management, selection of the appropriate suppliers and evaluation of their performance are identified as two of the crucial strategic issues for overall survival of the concerned manufacturing organization. To fulfill the long term objective of the organization and enhance the supply chain efficacy, the selection of the most reliable suppliers for varying input materials has been recognized as of immense importance. In this direction, activities of the purchasing department must be supported and delineated through the deployment of strong mathematical tools and techniques.

But, nowadays, manufacturing organizations need to pay more attention to various environmental issues as imposed by the concerned governments. These environmental issues primarily arise from constant decrement in the level of raw materials, increasing pollution and emission of greenhouse gases. Those organizations must streamline their manufacturing processes so as to minimally affect the environment. This can only be achieved through the augmentation of a green production system through the involvement of green suppliers in the entire supply chain. It has also been observed that the customers have now become more conscious in procuring more environmentally sensitive products, apart from their primary requirements of low cost high quality products. Thus the inclusion of green suppliers in the organizational supply chain has been observed as extremely important with respect to environment friendliness, green service and purchasing, energy conservation, green management, design for environment, carbon footprint and emissions, reverse logistics, water usage and recycling initiatives [1]. Besides consciousness about various environmental parameters, the concept of green suppliers should also include green information transfer as well as management and organization practices. Governmental regulation, social responsibility, customer pressure and commercial benefits are also responsible for effective green supplier selection. As the selection of the most appropriate green supplier pays more attention to various green factors, it would help the concerned manufacturing organization to supersede its other competitors. It not only helps in influencing the profitability and competitiveness of the organization, but also effectively enhances the performance of the entire supply chain. A wrong green supplier selection decision may adversely affect the health of an organization as well as its goodwill.

Green supplier selection has now become essential in today's manufacturing environment considering increasing pollution levels worldwide, which can be attributed to increased consumption as well as innovation and improvement in production techniques and technology. With growing awareness and focus on climate change action, both the manufacturers and suppliers are concerned about the environmental impact of the products produced and consumed. Increasing consumer attention on using environment friendly products and manufacturers' focus on carbon footprint along with the concept of sustainable development have led the manufacturers to rethink and reorient their production strategies, right from the raw material procurement. Hence, selection of suppliers who share the common idea of eco- 
friendliness and being 'green' in thinking is very important in today's competitive manufacturing environment. It not only helps in the fight against pollution, but also helps the organizations in green marketing while improving public perception and trust on their products.

For any manufacturing organization, selection of the most apposite green supplier is a complex decision-making task due to the involvement of various experts (decision-makers) from different related departments, like procurement, planning, production, quality control, etc. It has been identified as a multi-criteria decision-making (MCDM) problem where the best green supplier needs to be identified in the presence of a set of conflicting criteria [2]. In the green supplier selection process, a group of experts having dissimilar backgrounds, experiences, expertise and stature usually participate. They usually express their subjective judgments on the relative performance of the candidate green suppliers with respect to several evaluation criteria. The members of the group of experts also have different priority levels and preferences, raising the scope of inclusion of uncertainty, vagueness and hesitancy in the final decision. But, all the experts must aim at identifying a particular green supplier which would be quite similar to the ideal solution. A consensus decision thus must be arrived at after aggregating the individual decisions of all the participating experts. In the process of the green supplier selection and performance appraisal, the individual experts have the difficulty in expressing their judgments with specific numerical values as most of the evaluation criteria are qualitative in nature and the human cognition process is sometimes vague (uncertain). The experts always like to communicate their opinions through linguistic expressions, i.e. imprecise and unquantifiable information. Thus, there is an ardent need to deploy an effective mathematical tool to support and transform those linguistic opinions into appropriate quantitative values. The conventional linguistic computational models which have been developed based on different membership functions, ordinal scales and 2-tuple linguistic information can only describe the fuzziness in a group green supplier selection decision-making problem but they are unable to consider the inherent randomness present in that problem. Thus, in this paper, a group MCDM method while integrating the Cloud model with technique for order of preference by similarity to an ideal solution (TOPSIS) is employed for identifying the most suitable green supplier for an automobile manufacturing unit. This green supplier selection problem consists of five candidate alternatives and 12 evaluation criteria (59 sub-criteria). The Cloud model first converts the fuzziness and randomness of linguistic terms present in the group decision-making process into numerical values. The alternative green suppliers are subsequently evaluated and ranked using the TOPSIS method. A comparison of the proposed approach with other fuzzy- and intervalbased models ensures its effectiveness in accounting for the inherent randomness and fuzziness present in the green supplier selection process. Considering the inherent qualitative evaluation process, it can thus be augmented as an efficient tool in determining the success of supply chain of a manufacturing organization.

\section{LITERATURE REVIEW}

The present literature is flooded with the applications of various mathematical tools, especially MCDM methods for solving diverse green supplier selection problems for different manufacturing organizations. Kuo et al. [3] integrated artificial neural network with data envelopment analysis (DEA) and analytic network process (ANP) to solve a 
green supplier selection problem. Using fuzzy decision-making trial and evaluation laboratory (DEMATEL) method, Ashlaghi [4] identified the interrelations between different criteria in a green supplier selection problem. The corresponding criteria weights were estimated based on fuzzy ANP while a linear physical programming model was later employed to choose the best supplier. Dobos and Vörösmarty [5] adopted the method composite indicators along with DEA approach to identify a suitable weight system for addressing the green factors in a supplier selection problem. Yazdani [6] first applied analytic hierarchy process (AHP) to estimate the weights of different green supplier selection criteria while the fuzzy TOPSIS method was subsequently employed to rank the considered suppliers. Cao et al. [7] presented an intuitionistic fuzzy MCDM approach for solving green supplier selection problems based on intuitionistic fuzzy criteria values and unknown criteria weights. The TOPSIS method was finally integrated with the proposed model to rank the considered suppliers. For a green supplier selection problem, Hashemi et al. [8] first adopted ANP to study the interdependencies among different criteria and later applied grey relational analysis (GRA) to rank the considered suppliers. Chen et al. [9] determined the weights of different criteria using fuzzy AHP and subsequently ranked the candidate green suppliers based on the fuzzy TOPSIS method. Doğan et al. [10] applied an MCDM approach in the form of the fuzzy TOPSIS for selecting green suppliers in a manufacturing unit in Turkey. Ghorabaee et al. [11] proposed the application of weighted aggregated sum product assessment (WASPAS) method to solve green supplier selection problems with interval type-2 fuzzy sets. A sensitivity analysis was also performed to investigate the effects of criteria weights and model parameters on the ranking results to establish robustness of the novel approach. Based on linguistic data, Watróbski and Sałabun [12] evaluated the performance of 25 green suppliers in a cable bundle manufacturing unit using the fuzzy TOPSIS method. Yu and Hou [13] applied a modified multiplicative AHP (MMAHP) method to deal with a green supplier selection problem in an automobile manufacturing unit. The efficacy of the proposed approach was also validated based on real time data. Sahu et al. [14] solved a green supplier selection problem using a fuzzy-based multi-level MCDM approach and compared its performance with respect to the fuzzy TOPSIS method. Yazdani et al. [15] incorporated the applications of quality function deployment and house of quality matrix in a green supplier selection and evaluation problem, and finally ranked the candidate suppliers using the WASPAS method. Gavareshki et al. [16] presented an integrated approach for green supplier selection in a brake pad manufacturing unit. At first, interpretive structural modeling and fuzzy MICMAC (cross-impact matrix multiplication applied to classification) analysis were adopted to highlight the interaction of different categories along with their driving and dependence power. The AHP method was utilized to estimate the criteria weights and VIKOR (VIse kriterijumsko KOmpromisno Rangiranje) method was finally used to rank the candidate suppliers. Hashemzahi et al. [17] adopted the TOPSIS method under fuzzy environment to deal with a green supplier selection problem while considering several environmental issues. Qin et al. [18] applied TODIM (TOmada de Decisao Interativa Multicriterio), an interactive MCDM tool, to solve a green supplier selection problem based on interval type-2 fuzzy sets.

Shafique [19] proposed the combined application of DEMATEL, AHP and TOPSIS methods for performance appraisal of green suppliers under fuzzy environment. Based on the Cloud model and qualitative flexible multiple criteria (QUALIFLEX) method, Wang et 
al. [20] evaluated the relative performance of green suppliers in an auto manufacturing unit. Badi et al. [21] presented the novel application of combinative distance-based assessment (CODAS) method to select the most apposite supplier from a pool of six alternatives for a steelmaking company in Libya. The proposed approach was based on estimating the Euclidean distance and the Taxicab distance for evaluating the suitability of a particular supplier. Banaeian et al. [22] presented the application of three fuzzy MCDM methods, i.e. TOPSIS, VIKOR and GRA to deal with the selection of green suppliers in an agri-food industry. It was concluded that although all the three methods could provide the same supplier rankings, the fuzzy GRA would be the preferred method due to its less computational complexity. Under a hesitant fuzzy linguistic environment, Zhu and Li [23] applied hesitant 2tuple linguistic operator and Choquet integral operator to solve a green supplier selection problem. Abdullah et al. [24] studied the effects of different preference functions of preference ranking organization method for enrichment evaluation (PROMETHEE) in a green supplier selection problem. It was inferred that the best identified green supplier would remain unchanged for all the considered preference functions. Alguliyev et al. [25] proposed an MCDM technique for selection of candidates in e-voting based on a set of evaluation criteria. The considered candidates were finally rated using a positional ranking approach. Biswas et al. [26] adopted an ensemble approach based on a two-stage framework for effectively resolving portfolio selection problems. For fulfilling the objective, DEA, multi-attributive border approximation area comparison (MABAC) and entropy methods were integrated. Chatterjee and Stević [27] integrated fuzzy AHP and fuzzy TOPSIS methods to single out the most appropriate supplier based on a set of quantitative and qualitative criteria to streamline the purchasing process of a manufacturing organization. In order to solve a sustainable supplier selection problem, Durmić [28] identified a set of the most significant criteria using full consistency method (FUCOM) based on the opinions of a group of experts.

Liu et al. [29] identified green supplier selection as a typical multi-criteria group decision-making problem and presented the application of generalized ordered weighted hesitant fuzzy prioritized average operator to solve the same. Lu et al. [30] proposed a novel approach integrating the Cloud model and possibility degree for selection of the optimal green supplier in a Chinese straw biomass industry. Rashidi and Cullinane [31] compared the solutions derived from fuzzy TOPSIS and fuzzy DEA methods while identifying the best sustainable supplier for logistics service providers in Sweden. It was observed that the fuzzy TOPSIS could outperform the other technique with respect to computational complexity and robustness to variations in the number of suppliers. While applying the extended TOPSIS method under interval-valued Pythagorean fuzzy environment, $\mathrm{Yu}$ et al. [32] solved a sustainable supplier selection problem to aid the managers in taking the optimal decision. Yucesan et al. [33] combined the best-worst method and interval type-2 fuzzy TOPSIS for identifying the best green supplier in a plastic injection molding unit in Turkey. Žižović and Pamučar [34] developed a new level based weight assessment (LBWA) model for measuring the criteria weights for an MCDM problem. It was proved to be an efficient approach for defining the relations between the considered criteria and providing rational decisionmaking. Đalić et al. [35] employed fuzzy pivot pair-wise relative criteria importance assessment (PIPRECIA) and interval rough simple additive weighting (SAW) methods to solve a green supplier selection problem.

An extensive review of the past research studies clearly reveals that various fuzzy models, mainly intuitionistic model, interval type- 2 model, hesitant model, etc. have been 
employed to transform the vague qualitative information into numerical values; thereafter, the candidate green suppliers have been subsequently ranked using other MCDM tools, like AHP, ANP, TOPSIS, GRA, WASPAS, VIKOR, SAW, PIPRECIA, etc. In this paper, the application of the Cloud model is proposed to convert the linguistic information of the participating experts into quantitative data, taking into account both fuzziness and randomness present in the subjective judgments of the experts. The alternative green suppliers for the considered automobile manufacturing unit are later ranked using the TOPSIS method.

\section{CLOUD TOPSIS MODEL}

\subsection{Cloud model}

Let the set $U=\{x\}$ be the universe of discourse and $C$ be a qualitative attribute corresponding to $U$. Assume $\mu(x)$ as a random variable with a probability distribution, having values in $[0,1]$, to represent the membership degree of $x$ in $U$ to considered qualitative attribute $C$. Thus, a membership cloud can be represented as a mapping from the universe of discourse $U$ to the unit interval $[0,1]$, i.e.

$$
\boldsymbol{\mu}(x): U \rightarrow[0,1] \forall x \in U, \mathrm{x} \rightarrow \boldsymbol{\mu}(x)
$$

A Cloud can be defined as the distribution of $x$ in universe $U$ and Cloud drop is the value of every $x$ having membership degree $\mu(x)$. The uniqueness of Cloud model is that it can efficiently take into account both fuzziness and randomness in a qualitative attribute, and effectively reconstruct the qualitative attribute into the corresponding quantitative numbers using three numerical characteristics, i.e. Ex, En and He. Ex represents the expected value of the Cloud drop in the universe (the most representative qualitative attribute value). On the other hand, En signifies the degree of uncertainty of the considered qualitative attribute (distribution of the attribute), and it combines both fuzziness and randomness of the qualitative attribute. The term $\mathrm{He}$ denotes the uncertainty degree of En, which can be measured by the fuzziness and randomness of the entropy. Amongst various Cloud models, the normal Cloud model has become most popular because of its capability to deal with large number of uncertain phenomena in varied decision-making tasks. As there is ' $\pm 3 \sigma$ ' concept in statistics, the ' $3 E n$ ' rule in the Cloud model signifies that a Cloud drop within the interval $[E x-3 E n, E x+3 E n]$ can contribute to $99.73 \%$ Cloud drop in the universe [36].

When there are $n$ Clouds $x_{i}\left(E x_{i}, E n_{i}, H e_{i}\right)(i=1,2, \ldots, n)$ in the same universe of discourse and $w=\left(w_{1}, w_{2}, \ldots, w_{n}\right)\left(\sum_{i=1}^{n} w_{i}=1\right)$ is the weight vector, the weighted average Cloud $x_{w}$ can be obtained using the following expression:

$$
x_{w}=\sum_{i=1}^{n} w_{i} x_{i}=\left(\sum_{i=1}^{n} w_{i} E x_{i}, \sqrt{\sum_{i=1}^{n}\left(w_{i} E n_{i}\right)^{2}}, \sqrt{\sum_{i=1}^{n}\left(w_{i} H e_{i}\right)^{2}}\right)
$$

Weighted average Cloud $x_{w}$ can be employed to show the complete information of $n$ Clouds $x_{i \text { and }}$ help in aggregating varying opinions of the decision-makers as involved in a group decision-making task. 
When there are two Clouds $x_{i}\left(E x_{i}, E n_{i}, H e_{i}\right)$ and $x_{j}\left(E x_{j}, E n_{j}, H e_{j}\right)(i \neq j)$ in the same universe of discourse, the degree of inconsistency between them can be expressed as the difference of Cloud $d\left(x_{i}, x_{j}\right)$, which can be denoted as follows:

$$
\begin{gathered}
d\left(x_{i}, x_{j}\right)=\lambda_{1} \times d\left(E x_{i}, E x_{j}\right)+\lambda_{2} \times d\left(E n_{i}, E n_{j}\right)+\lambda_{3} \times d\left(H e_{i}, H e_{j}\right) \\
d\left(E x_{i}, E x_{j}\right)=\frac{\left|E x_{i}-E x_{j}\right|}{\max \left(E x_{i}+3 E n_{i}, E x_{j}+3 E n_{j}\right)-\min \left(E x_{i}-3 E n_{i}, E x_{j}-3 E n_{j}\right)} \\
d\left(E n_{i}, E n_{j}\right)=1-\frac{\min \left(E n_{i}, E n_{j}\right)}{\max \left(E n_{i}, E n_{j}\right)} \\
d\left(H e_{i}, H e_{j}\right)=1-\frac{\min \left(H e_{i}, H e_{j}\right)}{\max \left(H e_{i}, H e_{j}\right)} \\
\lambda_{1}+\lambda_{2}+\lambda_{3}=1\left(1 \geq \lambda_{1} \geq \lambda_{2} \geq \lambda_{3} \geq 0\right)
\end{gathered}
$$

where $\lambda_{1}, \lambda_{2}$ and $\lambda_{3}$ are the coefficients of difference, exhibiting the relative degree of importance with respect to the inconsistency of the two Clouds in Ex, En and He. Among the three numerical characteristics of the Cloud model, Ex has the maximum significance, followed by $E n$ and $H e$. Coefficients $\lambda_{\mathrm{k}}(k=1,2,3)$ can take different values based on the preferences of the concerned decision-makers. The difference of Cloud can be employed to quantitatively determine the difference level between different linguistic variables with respect to the same criterion.

In many real time decision-making scenarios, fuzziness and randomness in the accumulated information often appear in the human cognition process. The uncertain information is considered to be quite difficult to convert into quantitative measures. The concept of linguistic variables and interval representation are useful tools for expressing the degree of uncertainty in a decision-making process. There exists an effective way to transform both linguistic variables and interval representation into Cloud model [37]. Linguistic variables are often considered to express the subjective judgments (opinions) of different decision-makers (experts) and can take various levels, like poor, medium and good. The number of levels usually measures the degree of precision of the linguistic concept. But, in order to consider both precision and accessibility of the linguistic variables, the linguistic concept usually takes five levels, i.e. very poor, poor, medium, good and very good. Let the linguistic set considered by the experts be represented as $L=$ $\left\{l_{2-}=\right.$ very poor, $l_{1-}=$ poor, $l_{0}=$ medium, $l_{1+}=\operatorname{good}, l_{2+}=$ very good $\}$. Now, each of the elements of the above set can be denoted by a Cloud model having an interval $\left[x_{l}, x_{u}\right]$, where $x_{u}$ is the upper bound and $x_{l}$ is the lower bound of the interval, respectively. Based on the golden section ratio, the numerical characteristics of the five Clouds can be derived as follows [36]:

$$
\begin{gathered}
E x_{0}=\left(x_{1}+x_{u}\right) / 2 \\
E x_{2-}=x_{l}, E x_{2+}=x_{u} \\
E x_{1-}=E x_{0}-0.382 E x_{0}=0.618 E x_{0}
\end{gathered}
$$




$$
\begin{gathered}
E x_{1+}=E x_{0}+0.382 E x_{0}=1.382 E x_{0} \\
E n_{1-}=E n_{1+}=0.382\left(x_{u}-x_{l}\right) / 6 \\
E n_{0}=0.618 E n_{1+} \\
E n_{2-}=E n_{2+}=E n_{1+} / 0.618
\end{gathered}
$$

Similarly, the value of $\mathrm{He}_{0}$ can be derived as below:

$$
\begin{aligned}
& H e_{1-}=H e_{1_{+}}=H e_{0} / 0.618 \\
& H e_{2-}=H e_{2+}=H e_{1+} / 0.618
\end{aligned}
$$

When the values of $x_{l}$ and $x_{u}$ are set as 0 and 1 , respectively, the value of $H e_{0}$ becomes 0.01 . Now, different levels of the linguistic variables can be quantitatively expressed as follows:

$$
l_{i}\left(E x_{i}, E n_{i}, H e_{i}\right)=\left\{\begin{array}{c}
(0,0.103,0.026), i=1 \\
(0.309,0.064,0.016), i=2 \\
(0.5,0.039,0.01), i=3 \\
(0.691,0.064,0.016), i=4 \\
(1,0.103,0.026), i=5
\end{array}\right.
$$

where $l_{i}(\mathrm{i}=1,2,3,4,5)$ denotes different levels of the linguistic variable, i.e. very poor, poor, medium, good and very good. Thus, based on the above-cited mathematical formulations, varying values of the qualitative attributes can be quantitatively expressed through the Cloud model.

\subsection{Integration of the Cloud model with TOPSIS}

The Cloud model can be integrated with TOPSIS method using the following procedural steps [38]:

Step 1: For a group decision-making problem, there are $m$ alternatives $A_{i}(i=$ $1,2, \ldots, m), n$ evaluation criteria $C_{j}(j=1,2, \ldots, n)$ and $K$ decision-makers $D_{k}(k=1,2, \ldots, K)$. Now, based on Eqs. (6)-(15), the Cloud decision matrix $X_{k}=\left(E x_{k i j}, E n_{k i j}, H e_{k i j}\right)(k=$ $1,2, \ldots, K ; i=1,2, \ldots, m ; j=1,2, \ldots, n)$ can be formulated. In this matrix, the ratings of $i^{\text {th }}$ alternative with respect to $j^{\text {th }}$ criterion given by $k^{\text {th }}$ decision-maker are provided.

$$
X_{k}=\left[\begin{array}{cccc}
x_{k 11}\left(E x_{k 11}, E n_{k 11}, H e_{k 11}\right) & x_{k 12}\left(E x_{k 12}, E n_{k 12}, H e_{k 12}\right) & \ldots & x_{k 1 n}\left(E x_{k 1 n}, E n_{k 1 n}, H e_{k 1 n}\right) \\
x_{k 21}\left(E x_{k 21}, E n_{k 21}, H e_{k 21}\right) & x_{k 22}\left(E x_{k 22}, E n_{k 22}, H e_{k 22}\right) & \ldots & x_{k 2 n}\left(E x_{k 2 n}, E n_{k 2 n}, H e_{k 2 n}\right) \\
\ldots & \ldots & \ldots & \ldots \\
x_{k m 1}\left(E x_{k m 1}, E n_{k m 1}, H e_{k m 1}\right) & x_{k m 2}\left(E x_{k m 2}, E n_{k m 2}, H e_{k m 2}\right) & \ldots & x_{k m n}\left(E x_{k m n}, E n_{k m n}, H e_{k m n}\right)
\end{array}\right]
$$

Step 2: Compute the weighted average Cloud matrix

Using Eq. (1), the weighted average Cloud matrix $\left(X_{w}\right)$ can be obtained while multiplying each element of the Cloud decision matrix with the corresponding criterion weight. In the weighted average Cloud matrix, the overall level of evaluation results while 
aggregating the opinions of all the decision-makers is provided. The weighted average Cloud matrix can be expressed by:

$$
X_{w}=\sum_{k=1}^{K} w_{k}^{D} X_{k}=\left(\sum_{k=1}^{K} w_{k}^{D} E x_{k i j}, \sqrt{\sum_{k=1}^{K}\left(w_{k}^{D} E n_{k i j}\right)^{2}}, \sqrt{\sum_{k=1}^{K}\left(w_{k}^{D} H e_{k i j}\right)^{2}}\right)
$$

where $w_{k}^{D}(k=1,2, \ldots, K)$ shows the relative importance of opinion provided by $D_{k}$.

Step 3: Determine the criteria weights

Weight vector $w_{j}^{C}(j=1,2, \ldots, n)$ depicts the relative importance of $n$ criteria which can be determined by the evaluation process of the participating experts in the group decisionmaking process. (NIC)

Step 4: Identification of the positive ideal Cloud (PIC) and the negative ideal Cloud

Based on TOPSIS methodology, the selected best alternative should have the minimum distance from the PIC and the maximum distance from the NIC. Let $A^{+}=\left(x_{1}^{+} \ldots x_{j}^{+} \ldots x_{n}^{+}\right)$and $A^{-}=\left(x_{1}^{-} \ldots x_{j}^{-} \ldots x_{n}^{-}\right)$represent the PIC and NIC, respectively, and can be determined using the following equations:

$$
\begin{aligned}
& x_{j}^{+}=\left\{\begin{array}{l}
\left(\max E x_{i j}, \min E n_{i j}, \min H e_{i j}\right), j \in J^{*} \\
\left(\min E x_{i j}, \min E n_{i j}, \min H e_{i j}\right), j \in J^{\prime}
\end{array}\right. \\
& x_{j}^{-}=\left\{\begin{array}{l}
\left(\min E x_{i j}, \max E n_{i j}, \max H e_{i j}\right), j \in J^{*} \\
\left(\max E x_{i j}, \max E n_{i j}, \max H e_{i j}\right), j \in J^{\prime}
\end{array}\right.
\end{aligned}
$$

where $J^{*}$ is the set of beneficial criteria and $J^{\prime}$ is the set of non-beneficial (cost) criteria.

Step 5: Compute the difference of Cloud from the PIC $\left(A^{+}\right)$and the NIC $\left(A^{-}\right)$for every alternative $A_{i}$.

$$
\begin{aligned}
& d_{i}^{+}=d\left(A_{i}, A^{+}\right)=\sqrt{\sum_{j=1}^{n}\left[w_{j}^{C} d\left(x_{i j}, x_{j}^{+}\right)\right]^{2}} \\
& d_{i}^{-}=d\left(A_{i}, A^{-}\right)=\sqrt{\sum_{j=1}^{n}\left[w_{j}^{C} d\left(x_{i j}, x_{j}^{-}\right)\right]^{2}}
\end{aligned}
$$

where $w_{j}^{C}$ is the weight of the criterion $C_{j}$, and $d\left(x_{i j}, x_{j}\right)$ is the difference of Cloud between Cloud $x_{i j}$ and Cloud $x_{j}$.

Step 6: Estimate relative closeness degree $f_{i}$ for each alternative $A_{i}$ to the PIC using the following expression:

$$
f_{i}=\frac{d_{i}^{-}}{d_{i}^{+}+d_{i}^{-}}
$$

Step 7: Arrange the values of relative closeness degree $f_{i}$ in descending order and rank the considered alternatives. The higher is the value of $f_{i}$, the better is the alternative $A_{i}$, because it is closer to the PIC. 


\section{ILLUSTRATIVE EXAMPLE}

It has already been highlighted that the selection of the most suitable green supplier for any manufacturing organization is extremely crucial for its competitive effectiveness and success of the entire supply chain system. The performance of the alternative suppliers is usually evaluated based on several green criteria, with a scope of inclusion of fuzziness and randomness in the qualitative judgments due to difference in the human cognition process. In this paper, an attempt is put forward to apply the Cloud TOPSIS model to identify the best suited green supplier in an automobile manufacturing unit. This illustrative example deals with five potential green suppliers $A_{i}(i=1,2,3,4,5)$ to be appraised with respect to 12 evaluation criteria $C_{j}(j=1,2, \ldots, 12)$ by four experts $D_{k}(k=1,2,3,4)$. These four experts are chosen as one for the procurement, production planning and control, manufacturing and quality control departments of the considered unit. These evaluation criteria are quality, finance, service, delivery, capability of the supplier, environment management, management competency, corporate social responsibility, pollution control, green product, green image and hazardous substance management [39]. It can be clearly noted that the list of the criteria not only includes the conventional evaluation attributes, but also some major green parameters. Each of these criteria has also several sub-criteria, as elaborated in Tables 1-12. These tables provide the corresponding definitions for each of the sub-criteria as considered in the green supplier selection problem. It is worthwhile to mention here that amongst those sub-criteria, some are beneficial in nature where their higher values are always required, and the remaining are non-beneficial (cost) criteria requiring their lower values.

Table 1 Quality and its different sub-criteria

\begin{tabular}{|c|c|c|}
\hline Criterion & Sub-criteria & Definition \\
\hline \multirow{5}{*}{$\begin{array}{l}\text { Quality } \\
\qquad\left(\mathrm{C}_{1}\right)\end{array}$} & Quality assurance $\left(\mathrm{C}_{11}\right)$ & $\begin{array}{l}\text { Desired quality level maintenance certificate issued by } \\
\text { third party to ensure green product specification fulfillment }\end{array}$ \\
\hline & Rejection rate $\left(\mathrm{C}_{12}\right)$ & $\begin{array}{l}\text { Percentage of rejection of supplied materials after inspection } \\
\text { and testing }\end{array}$ \\
\hline & $\begin{array}{l}\text { Warranties and claim } \\
\text { policies }\left(\mathrm{C}_{13}\right)\end{array}$ & $\begin{array}{l}\text { Provision of warranties and claim policies by the supplier } \\
\text { or agreements for the faulty products }\end{array}$ \\
\hline & $\begin{array}{l}\text { Capability of handling } \\
\text { abnormal quality }\left(\mathrm{C}_{14}\right)\end{array}$ & $\begin{array}{l}\text { Capability to achieve the abnormal customer quality } \\
\text { specification without compromising on the existing price of } \\
\text { the product }\end{array}$ \\
\hline & $\begin{array}{l}\text { Quality-related } \\
\text { certificates }\left(\mathrm{C}_{15}\right)\end{array}$ & $\begin{array}{l}\text { Ensure high quality control of the products and provide } \\
\text { the quality concerned certificates, like ISO9000, QS9000 } \\
\text { etc. }\end{array}$ \\
\hline
\end{tabular}

Table 2 Finance and its sub-criteria

\begin{tabular}{ccl}
\hline Criterion & Sub-criteria & \multicolumn{1}{c}{ Definition } \\
& Purchasing price $\left(\mathrm{C}_{21}\right)$ & $\begin{array}{l}\text { Minimize product price without affecting the quality which } \\
\text { includes warranty cost, processing cost, cost of greening, etc. }\end{array}$ \\
$\begin{array}{ccl}\text { Finance } \\
\left(\mathrm{C}_{2}\right)\end{array}$ & $\begin{array}{c}\text { Price performance value }\left(\mathrm{C}_{22}\right) \\
\text { Transportation cost }\left(\mathrm{C}_{23}\right)\end{array}$ & $\begin{array}{l}\text { High level of performance with respect to product value } \\
\text { Fixed cost of transportation for product supply } \\
\text { Quantity discount }\left(\mathrm{C}_{24}\right)\end{array}$ \\
$\begin{array}{l}\text { Discount offered by the supplier based on the quantity of } \\
\text { purchase }\end{array}$ \\
\hline
\end{tabular}


Table 3 Service along with its different sub-criteria

\begin{tabular}{|c|c|c|}
\hline Criterion & Sub-criteria & Definition \\
\hline \multirow{6}{*}{$\begin{array}{l}\text { Service } \\
\left(\mathrm{C}_{3}\right)\end{array}$} & $\begin{array}{l}\text { Rate of processing order } \\
\text { form }\left(C_{31}\right)\end{array}$ & Satisfactory processing of customer orders \\
\hline & $\begin{array}{c}\text { Capability of delivery on } \\
\text { time }\left(\mathrm{C}_{32}\right)\end{array}$ & $\begin{array}{l}\text { Ability to deliver product on time according to the } \\
\text { customer agreement }\end{array}$ \\
\hline & $\begin{array}{l}\text { Degree of information } \\
\text { modernized }\left(\mathrm{C}_{33}\right)\end{array}$ & System for tracking of current orders \\
\hline & Credible delivery $\left(\mathrm{C}_{34}\right)$ & \multirow{3}{*}{$\begin{array}{l}\text { Reputation and trust of customer towards the supplier } \\
\text { Attention given to customer service } \\
\text { Concern for the environment and interest to reduce } \\
\text { impact on it during production }\end{array}$} \\
\hline & Responsiveness $\left(\mathrm{C}_{35}\right)$ & \\
\hline & Willingness $\left(\mathrm{C}_{36}\right)$ & \\
\hline
\end{tabular}

Table 4 Delivery and its various sub-criteria

\begin{tabular}{ccl}
\hline Criterion & Sub-criteria & \multicolumn{1}{c}{ Definition } \\
\hline Delivery & Order fulfillment rate $\left(\mathrm{C}_{41}\right)$ & Order delivery at the right time \\
$\left(\mathrm{C}_{4}\right)$ & Lead time $\left(\mathrm{C}_{42}\right)$ & Time between order placement and order arrival \\
\hline
\end{tabular}

Table 5 Capability of supplier and its different sub-criteria

\begin{tabular}{|c|c|c|}
\hline Criterion & Sub-criteria & Definition \\
\hline \multirow{8}{*}{$\begin{array}{l}\text { Capability } \\
\text { of supplier } \\
\qquad\left(\mathrm{C}_{5}\right)\end{array}$} & Supplying capability $\left(\mathrm{C}_{51}\right)$ & $\begin{array}{l}\text { Ability to fulfill promises to the customer and meet } \\
\text { shortcomings }\end{array}$ \\
\hline & Level of technique $\left(\mathrm{C}_{52}\right)$ & $\begin{array}{l}\text { Adoption of novel tools to maintain scheduling and } \\
\text { delivery tasks }\end{array}$ \\
\hline & $\begin{array}{l}\text { Capability of product } \\
\text { development }\left(\mathrm{C}_{53}\right)\end{array}$ & Ability to augment innovative designs \\
\hline & Capability of R \& D $\left(\mathrm{C}_{54}\right)$ & $\begin{array}{l}\text { Proper setup for the related research and development } \\
\text { activities }\end{array}$ \\
\hline & Technology level $\left(\mathrm{C}_{55}\right)$ & Technology development for more efficient production \\
\hline & Capability of design $\left(\mathrm{C}_{56}\right)$ & $\begin{array}{l}\text { Competence to design and develop new products to } \\
\text { fulfill the end requirements }\end{array}$ \\
\hline & $\begin{array}{l}\text { Flexibility of supplier } \\
\qquad\left(\mathrm{C}_{57}\right)\end{array}$ & $\begin{array}{l}\text { Ability of scheduling, modifying and replacing orders } \\
\text { on demand }\end{array}$ \\
\hline & $\begin{array}{l}\text { Supplier stock management } \\
\left(\mathrm{C}_{58}\right)\end{array}$ & Efficient inventory control \\
\hline
\end{tabular}

Table 6 Sub-criteria for environment management

\begin{tabular}{|c|c|c|}
\hline Criterion & Sub-criteria & Definition \\
\hline \multirow{4}{*}{$\begin{array}{l}\text { Environment } \\
\text { management } \\
\left(\mathrm{C}_{6}\right)\end{array}$} & $\begin{array}{l}\text { Environmental protection } \\
\text { policies/plans }\left(\mathrm{C}_{61}\right)\end{array}$ & $\begin{array}{l}\text { Efficacy in proposing effective plans used for } \\
\text { environment focused management }\end{array}$ \\
\hline & $\begin{array}{l}\text { Implementation and } \\
\text { planning }\left(\mathrm{C}_{62}\right)\end{array}$ & Application of processes for environment management \\
\hline & $\begin{array}{l}\text { Continuous environment } \\
\text { improvement (C63) }\end{array}$ & $\begin{array}{l}\text { Continuous endeavor to use green processes and their } \\
\text { improvement to reduce environmental impact }\end{array}$ \\
\hline & $\begin{array}{l}\text { Energy using product } \\
\left(\mathrm{C}_{64}\right)\end{array}$ & $\begin{array}{l}\text { Product design to meet eco-design requirements for } \\
\text { energy }\end{array}$ \\
\hline
\end{tabular}


Table 7 Sub-criteria for management competency

\begin{tabular}{|c|c|c|}
\hline Criterion & Sub-criteria & Definition \\
\hline $\begin{array}{c}\text { Management } \\
\text { competency } \\
\left(\mathrm{C}_{7}\right)\end{array}$ & $\begin{array}{l}\text { Involvement of partners } \\
\qquad\left(\mathrm{C}_{71}\right) \\
\text { Exchange of information } \\
\left(\mathrm{C}_{72}\right) \\
\text { Environment training }\left(\mathrm{C}_{73}\right)\end{array}$ & $\begin{array}{l}\text { Motivation of management to use environment } \\
\text { friendly and clean production processes } \\
\text { Willingness to share (or receive) product related } \\
\text { information with (from) the customer } \\
\text { Training related to obtain a green product }\end{array}$ \\
\hline
\end{tabular}

Table 8 Corporate social responsibility and its different sub-criteria

\begin{tabular}{|c|c|c|}
\hline Criterion & Sub-criteria & Definition \\
\hline \multirow{4}{*}{$\begin{array}{c}\text { Corporate } \\
\text { social } \\
\text { responsibility } \\
\left(\mathrm{C}_{8}\right)\end{array}$} & $\begin{array}{l}\text { Interests and rights of } \\
\text { employees }\left(\mathrm{C}_{81}\right)\end{array}$ & $\begin{array}{l}\text { Focus on labor relations, interest of the employees and } \\
\text { human rights }\end{array}$ \\
\hline & Rights of stakeholder $\left(\mathrm{C}_{82}\right)$ & $\begin{array}{l}\text { To meet the interests and rights of the shareholders, } \\
\text { customers and communities }\end{array}$ \\
\hline & $\begin{array}{l}\text { Information disclosure } \\
\qquad\left(\mathrm{C}_{83}\right)\end{array}$ & $\begin{array}{l}\text { Transparency of information regarding supplier business } \\
\text { activities }\end{array}$ \\
\hline & Respect for the policy $\left(\mathrm{C}_{84}\right)$ & $\begin{array}{l}\text { Compliance with local regulations and policies, and } \\
\text { avoidance of illegal activities }\end{array}$ \\
\hline
\end{tabular}

Table 9 Pollution control with its sub-criteria

\begin{tabular}{|c|c|c|}
\hline Criterion & Sub-criteria & Definition \\
\hline \multirow{5}{*}{$\begin{array}{l}\text { Pollution } \\
\text { control }\left(\mathrm{C}_{9}\right)\end{array}$} & Use of harmful materials & Limit and minimize use of harmful and hazardous \\
\hline & Air emission $\left(\mathrm{C}_{92}\right)$ & $\begin{array}{l}\text { Effective control and treatment of hazardous } \\
\text { materials, like } \mathrm{SO}_{2}, \mathrm{NH}_{3}, \mathrm{CO} \text { and } \mathrm{HC} 1\end{array}$ \\
\hline & Waste water $\left(\mathrm{C}_{93}\right)$ & Waste water control and treatment \\
\hline & Solid waste $\left(\mathrm{C}_{94}\right)$ & Capability to treat, use and dispose solid waste \\
\hline & Energy consumption $\left(\mathrm{C}_{95}\right)$ & Energy consumption control \\
\hline
\end{tabular}

Table 10 Green product and its various sub-criteria

\begin{tabular}{ccl}
\hline Criterion & Sub-criteria & \multicolumn{1}{c}{ Definition } \\
\hline Recycle $\left(\mathrm{C}_{101}\right)$ & $\begin{array}{l}\text { Ability to convert an already used product into new, } \\
\text { reusable product, thereby minimizing damage to } \\
\text { environment }\end{array}$ \\
& $\begin{array}{c}\text { Green packaging }\left(\mathrm{C}_{102}\right) \\
\text { Green certifications } \\
\left(\mathrm{C}_{103}\right)\end{array}$ & $\begin{array}{l}\text { Use of green materials in product packaging } \\
\text { Provision of green related certificates by product } \\
\text { suppliers }\end{array}$ \\
$\begin{array}{ccc}\text { Green product } \\
\left(\mathrm{C}_{10}\right)\end{array}$ & $\begin{array}{c}\text { Green production }\left(\mathrm{C}_{104}\right) \\
\text { Reuse }\left(\mathrm{C}_{105}\right)\end{array}$ & $\begin{array}{l}\text { Use of environment friendly and clean production setup } \\
\text { Ability to reutilize previously used products or their } \\
\text { components }\end{array}$ \\
& Re-manufacture $\left(\mathrm{C}_{106}\right)$ & $\begin{array}{l}\text { Usage of certain components from waste products for } \\
\text { future use } \\
\text { Ability to destroy or dispose of the harmful materials in a } \\
\text { green way }\end{array}$ \\
& Disposal $\left(\mathrm{C}_{107}\right)$ & $\begin{array}{l}\text { Cost of treatment and disposal at the end of product life } \\
\text { cycle }\end{array}$ \\
& Cost of component disposat \\
$\left(\mathrm{C}_{108}\right)$ &
\end{tabular}


Table 11 Green image and its five sub-criteria

\begin{tabular}{|c|c|c|}
\hline Criterion & Sub-criteria & Definition \\
\hline $\begin{array}{l}\text { Green image } \\
\qquad\left(\mathrm{C}_{11}\right)\end{array}$ & $\begin{array}{l}\text { Materials used in the } \\
\text { supplied components to } \\
\text { reduce the impact on } \\
\text { natural resources }\left(\mathrm{C}_{111}\right) \\
\text { Ability to alter process and } \\
\text { product for reducing the } \\
\text { impact on natural resources } \\
\left.\text { ( } \mathrm{C}_{112}\right) \\
\text { Green customers' market } \\
\text { share }\left(\mathrm{C}_{113}\right) \\
\text { Ratio of green customers to } \\
\text { total customers }\left(\mathrm{C}_{114}\right) \\
\text { Green innovation }\left(\mathrm{C}_{115}\right)\end{array}$ & $\begin{array}{l}\text { Retention and increase of customers buying green } \\
\text { products } \\
\text { Ratio of customers that buy green products to the total } \\
\text { customers of the supplier } \\
\text { Innovative tools focusing on green product development } \\
\text { and minimization of impact on environment }\end{array}$ \\
\hline
\end{tabular}

Table 12 Sub-criteria for hazardous substance management

\begin{tabular}{|c|c|c|}
\hline Criterion & Sub-criteria & Definition \\
\hline \multirow{4}{*}{$\begin{array}{l}\text { Hazardous } \\
\text { substance } \\
\text { management } \\
\qquad\left(\mathrm{C}_{12}\right)\end{array}$} & $\begin{array}{l}\text { Management for hazardous } \\
\text { substances }\left(\mathrm{C}_{121}\right)\end{array}$ & $\begin{array}{l}\text { Proper maintenance and preventive management } \\
\text { approaches related to use and disposal of hazardous } \\
\text { materials }\end{array}$ \\
\hline & $\begin{array}{l}\text { Prevention of mixed } \\
\text { materials }\left(\mathrm{C}_{122}\right)\end{array}$ & $\begin{array}{l}\text { Production procedure standards maintenance for } \\
\text { differentiating between green and non-green materials }\end{array}$ \\
\hline & Process auditing $\left(\mathrm{C}_{123}\right)$ & $\begin{array}{l}\text { Effective auditing system to examine process } \\
\text { conditions, parameter-setup document management, } \\
\text { product change management, disqualified product } \\
\text { management, improvement approaches and quality } \\
\text { management system for production environment }\end{array}$ \\
\hline & $\begin{array}{l}\text { Warehouse management } \\
\qquad\left(\mathrm{C}_{124}\right)\end{array}$ & $\begin{array}{l}\text { Level of warehouse management and space allocation } \\
\text { for proper resource storage and maintenance }\end{array}$ \\
\hline
\end{tabular}

In Tables 13-24, where the detailed Cloud TOPSIS method-based calculations are exhibited, those beneficial and non-beneficial criteria are distinguished with $(+)$ and (-) symbols, respectively. For simplicity of calculations, all the sub-criteria are assumed to have equal weights and all the four experts $\left(\mathrm{E}_{1}, \mathrm{E}_{2}, \mathrm{E}_{3}\right.$ and $\left.\mathrm{E}_{4}\right)$ also have equal importance, i.e. $w_{1}^{D}=w_{2}^{D}=w_{3}^{D}=w_{4}^{D}=0.25$. The values of the coefficients of difference are taken here as $\lambda_{1}=1 / 2, \lambda_{2}=1 / 3$ and $\lambda_{3}=1 / 6$. Tables 13-24 exhibit the original decision matrices containing judgments by different experts on the considered five alternative green suppliers with respect to all the sub-criteria. In the green supplier performance appraisal and evaluation process by the experts, $\{$ Very poor, Poor, Medium, Good, Very good $\}=\{\mathrm{VP}, \mathrm{P}, \mathrm{M}, \mathrm{G}, \mathrm{VG}]$ is the ordered set adopted to describe the human cognition for the beneficial sub-criteria, whereas $\{$ Very low, Low, Medium, High, Very high $\}=\{\mathrm{VL}, \mathrm{L}, \mathrm{M}, \mathrm{H}, \mathrm{VH}\}$ is the ordered set employed to highlight the expert's judgments for the non-beneficial criteria. For example, in Table 13 , the performance of green supplier $S_{1}$ with respect to sub-criteria quality assurance $\left(\mathrm{C}_{11}\right)$ (a beneficial criterion) has been appraised as $\operatorname{good}(\mathrm{G})$ by all the participating experts. 
Table 13 Original decision matrix and weighted average Cloud matrix for criterion $\mathrm{C}_{1}$

\begin{tabular}{|c|c|c|c|c|c|c|c|c|c|}
\hline Criterion & $\begin{array}{c}\text { Sub- } \\
\text { criteria }\end{array}$ & $\begin{array}{c}\text { Green } \\
\text { supplier }\end{array}$ & $\mathrm{E}_{1}$ & $\mathrm{E}_{2}$ & $\mathrm{E}_{3}$ & $\mathrm{E}_{4}$ & \multicolumn{3}{|c|}{ Weighted average Cloud matrix } \\
\hline \multirow{25}{*}{$\mathrm{C}_{1}$} & \multirow{5}{*}{$\mathrm{C}_{11}(+)$} & $\mathrm{S}_{1}$ & $\mathrm{G}$ & G & G & $\mathrm{G}$ & 0.6910 & 0.032 & 0.0080 \\
\hline & & $\mathrm{S}_{2}$ & G & $\mathrm{F}$ & G & G & 0.6432 & 0.0294 & 0.0074 \\
\hline & & $\mathrm{S}_{3}$ & G & $\mathrm{F}$ & G & G & 0.6432 & 0.0294 & 0.0074 \\
\hline & & $\mathrm{S}_{4}$ & G & $\mathrm{P}$ & G & G & 0.5955 & 0.032 & 0.0080 \\
\hline & & $\mathrm{S}_{5}$ & VG & $\mathrm{VG}$ & VG & G & 0.9227 & 0.0474 & 0.0119 \\
\hline & \multirow{5}{*}{$\mathrm{C}_{12}(-)$} & $S_{1}$ & $\mathrm{~L}$ & $\mathrm{~L}$ & $\mathrm{~L}$ & $\mathrm{M}$ & 0.3567 & 0.0294 & 0.0074 \\
\hline & & $\mathrm{S}_{2}$ & $\mathrm{~L}$ & $\mathrm{~L}$ & $\mathrm{~L}$ & M & 0.3567 & 0.0294 & 0.0074 \\
\hline & & $\mathrm{S}_{3}$ & M & M & $\mathrm{L}$ & $\mathrm{L}$ & 0.4045 & 0.0265 & 0.0067 \\
\hline & & $\mathrm{S}_{4}$ & $\mathrm{~L}$ & $\mathrm{~L}$ & $\mathrm{~L}$ & M & 0.3567 & 0.0294 & 0.0074 \\
\hline & & $\mathrm{S}_{5}$ & $\mathrm{~L}$ & M & $\mathrm{L}$ & $\mathrm{L}$ & 0.3567 & 0.0294 & 0.0074 \\
\hline & \multirow{5}{*}{$\mathrm{C}_{13}(+)$} & $\mathrm{S}_{1}$ & G & VG & G & G & 0.7682 & 0.0378 & 0.0094 \\
\hline & & $\mathrm{S}_{2}$ & G & $\mathrm{G}$ & G & $\mathrm{F}$ & 0.6432 & 0.0294 & 0.0074 \\
\hline & & $\mathrm{S}_{3}$ & G & G & G & G & 0.6910 & 0.032 & 0.0080 \\
\hline & & $\mathrm{S}_{4}$ & G & G & $\mathrm{G}$ & G & 0.6910 & 0.032 & 0.0080 \\
\hline & & $\mathrm{S}_{5}$ & VG & $\mathrm{G}$ & $\mathrm{G}$ & VG & 0.8455 & 0.0429 & 0.0107 \\
\hline & \multirow{5}{*}{$\mathrm{C}_{14}(+)$} & $\mathrm{S}_{1}$ & $\mathrm{G}$ & G & $\mathrm{F}$ & $\mathrm{G}$ & 0.6432 & 0.0294 & 0.0074 \\
\hline & & $\mathrm{S}_{2}$ & VG & VG & $\mathrm{G}$ & $\mathrm{G}$ & 0.8455 & 0.0429 & 0.0107 \\
\hline & & $\mathrm{S}_{3}$ & G & $\mathrm{G}$ & G & G & 0.691 & 0.032 & 0.0080 \\
\hline & & $\mathrm{S}_{4}$ & G & VG & F & $\mathrm{F}$ & 0.6727 & 0.0333 & 0.0084 \\
\hline & & $\mathrm{S}_{5}$ & VG & $\mathrm{G}$ & $\mathrm{G}$ & VG & 0.8455 & 0.0429 & 0.0107 \\
\hline & \multirow{5}{*}{$\mathrm{C}_{15}(+)$} & $\mathrm{S}_{1}$ & $\mathrm{G}$ & $\mathrm{F}$ & $\mathrm{G}$ & $\mathrm{P}$ & 0.5477 & 0.0294 & 0.0074 \\
\hline & & $\mathrm{S}_{2}$ & G & F & F & $\mathrm{F}$ & 0.5477 & 0.0233 & 0.0059 \\
\hline & & $\mathrm{S}_{3}$ & G & G & G & $\mathrm{P}$ & 0.5955 & 0.032 & 0.0080 \\
\hline & & $\mathrm{S}_{4}$ & G & G & VG & $\mathrm{G}$ & 0.7682 & 0.0378 & 0.0095 \\
\hline & & $\mathrm{S}_{5}$ & VG & VG & VG & G & 0.9227 & 0.0474 & 0.0119 \\
\hline
\end{tabular}

Table 14 Original decision matrix and weighted average Cloud matrix for criterion $\mathrm{C}_{2}$

\begin{tabular}{cccccccccc}
\hline Criterion & $\begin{array}{c}\text { Sub- } \\
\text { criteria }\end{array}$ & $\begin{array}{c}\text { Green } \\
\text { supplier }\end{array}$ & $\mathrm{E}_{1}$ & $\mathrm{E}_{2}$ & $\mathrm{E}_{3}$ & $\mathrm{E}_{4}$ & \multicolumn{2}{c}{ Weighted average Cloud matrix } \\
\hline & & $\mathrm{S}_{1}$ & $\mathrm{H}$ & $\mathrm{M}$ & $\mathrm{H}$ & $\mathrm{H}$ & 0.6432 & 0.0293 & 0.0074 \\
& $\mathrm{~S}_{2}$ & $\mathrm{~L}$ & $\mathrm{H}$ & $\mathrm{H}$ & $\mathrm{H}$ & 0.5955 & 0.032 & 0.0080 \\
& $\mathrm{C}_{21}(-)$ & $\mathrm{S}_{3}$ & $\mathrm{M}$ & $\mathrm{H}$ & $\mathrm{M}$ & $\mathrm{H}$ & 0.5955 & 0.0265 & 0.0067 \\
& & $\mathrm{~S}_{4}$ & $\mathrm{~L}$ & $\mathrm{H}$ & $\mathrm{H}$ & $\mathrm{H}$ & 0.5955 & 0.032 & 0.0080 \\
& & $\mathrm{~S}_{5}$ & $\mathrm{VH}$ & $\mathrm{VH}$ & $\mathrm{VH}$ & $\mathrm{VH}$ & 1 & 0.0515 & 0.0130 \\
\cline { 3 - 9 } & & $\mathrm{S}_{1}$ & $\mathrm{G}$ & $\mathrm{VG}$ & $\mathrm{G}$ & $\mathrm{VG}$ & 0.8455 & 0.0378 & 0.0108 \\
& & $\mathrm{~S}_{2}$ & $\mathrm{~F}$ & $\mathrm{G}$ & $\mathrm{G}$ & $\mathrm{G}$ & 0.6432 & 0.0356 & 0.0074 \\
& & $\mathrm{~S}_{3}$ & $\mathrm{G}$ & $\mathrm{VG}$ & $\mathrm{VG}$ & $\mathrm{G}$ & 0.8455 & 0.0265 & 0.0108 \\
& $\mathrm{C}_{22}(+)$ & $\mathrm{S}_{4}$ & $\mathrm{G}$ & $\mathrm{VG}$ & $\mathrm{G}$ & $\mathrm{VG}$ & 0.8455 & 0.0265 & 0.0108 \\
& & $\mathrm{~S}_{5}$ & $\mathrm{VG}$ & $\mathrm{VG}$ & $\mathrm{VG}$ & $\mathrm{VG}$ & 1 & 0.0265 & 0.0130 \\
\hline & & $\mathrm{S}_{1}$ & $\mathrm{H}$ & $\mathrm{H}$ & $\mathrm{VL}$ & $\mathrm{L}$ & 0.4227 & 0.0378 & 0.0095 \\
& & $\mathrm{~S}_{2}$ & $\mathrm{~L}$ & $\mathrm{H}$ & $\mathrm{VH}$ & $\mathrm{M}$ & 0.6250 & 0.0294 & 0.0090 \\
& & $\mathrm{~S}_{3}$ & $\mathrm{M}$ & $\mathrm{L}$ & $\mathrm{M}$ & $\mathrm{H}$ & 0.5000 & 0.0265 & 0.0067 \\
& & $\mathrm{~S}_{4}$ & $\mathrm{~L}$ & $\mathrm{H}$ & $\mathrm{M}$ & $\mathrm{M}$ & 0.5000 & 0.032 & 0.0067 \\
& $\mathrm{C}_{23}(-)$ & $\mathrm{S}_{5}$ & $\mathrm{H}$ & $\mathrm{H}$ & $\mathrm{M}$ & $\mathrm{M}$ & 0.5955 & 0.0356 & 0.0067 \\
\hline & & $\mathrm{S}_{1}$ & $\mathrm{P}$ & $\mathrm{VG}$ & $\mathrm{G}$ & $\mathrm{G}$ & 0.6727 & 0.032 & 0.0095 \\
& & $\mathrm{~S}_{2}$ & $\mathrm{G}$ & $\mathrm{G}$ & $\mathrm{P}$ & $\mathrm{F}$ & 0.5477 & 0.032 & 0.0074 \\
& & $\mathrm{~S}_{3}$ & $\mathrm{G}$ & $\mathrm{F}$ & $\mathrm{G}$ & $\mathrm{F}$ & 0.5955 & 0.032 & 0.0067 \\
& & $\mathrm{~S}_{4}$ & $\mathrm{G}$ & $\mathrm{G}$ & $\mathrm{P}$ & $\mathrm{G}$ & 0.5955 & 0.0428 & 0.0080 \\
& & $\mathrm{~S}_{5}$ & $\mathrm{G}$ & $\mathrm{VG}$ & $\mathrm{F}$ & $\mathrm{G}$ & 0.7205 & 0.0515 & 0.0089 \\
\hline & $\mathrm{C}_{24}(+)$ & & & & & & & & \\
& & & & & & &
\end{tabular}


Based on the Cloud model and Eq. (15), this level of the linguistic expression can be numerically expressed as $(0.691,0.064,0.016)$. Similarly, all the linguistic decisions as opined by the experts for the five candidate green suppliers with respect to the remaining sub-criteria are converted into the corresponding quantitative values. The last columns of Tables 13-24 represent the weighted average Cloud matrices for all the considered subcriteria for this green supplier selection problem. The elements of the weighted average Cloud matrices are determined based on Eq. (17). Now, using Eqn. (18)-(22), the values of the relative closeness degree are computed for all the green suppliers, as provided in Table 25. Based on these values, alternative $S_{4}$ is identified as the best green supplier for the considered automobile manufacturing unit so as to strengthen its supply chain system. Amongst the five green suppliers, supplier $S_{1}$ is the worst preferred choice.

Table 15 Original decision matrix and weighted average Cloud matrix for criterion $\mathrm{C}_{3}$

\begin{tabular}{|c|c|c|c|c|c|c|c|c|c|}
\hline \multirow{2}{*}{ Criterion } & $\begin{array}{c}\text { Sub- } \\
\text { criteria }\end{array}$ & \multirow{2}{*}{$\begin{array}{c}\begin{array}{c}\text { Green } \\
\text { supplier }\end{array} \\
\mathrm{S}_{1}\end{array}$} & \multirow{2}{*}{$\frac{\mathrm{E}_{1}}{\mathrm{G}}$} & \multirow{2}{*}{$\frac{\mathrm{E}_{2}}{\mathrm{G}}$} & \multirow{2}{*}{$\frac{\mathrm{E}_{3}}{\mathrm{G}}$} & \multirow{2}{*}{$\frac{E_{4}}{G}$} & \multicolumn{3}{|c|}{ Weighted average Cloud matrix } \\
\hline & \multirow{5}{*}{$\mathrm{C}_{31}(+)$} & & & & & & 0.6910 & 0.0429 & 0.0080 \\
\hline \multirow{29}{*}{$\mathrm{C}_{3}$} & & $\mathrm{~S}_{2}$ & $\mathrm{G}$ & $\mathrm{G}$ & $\mathrm{G}$ & $\mathrm{G}$ & 0.6910 & 0.0265 & 0.0080 \\
\hline & & $\mathrm{S}_{3}$ & $\mathrm{G}$ & $\mathrm{G}$ & $\mathrm{G}$ & $\mathrm{G}$ & 0.6910 & 0.0232 & 0.0080 \\
\hline & & $\mathrm{S}_{4}$ & VG & $\mathrm{G}$ & $\mathrm{G}$ & VG & 0.8455 & 0.0356 & 0.0108 \\
\hline & & $\mathrm{S}_{5}$ & VG & VG & VG & VG & 1 & 0.0410 & 0.0130 \\
\hline & \multirow{5}{*}{$\mathrm{C}_{32}(+)$} & $\mathrm{S}_{1}$ & VP & $\mathrm{P}$ & $\mathrm{P}$ & VP & 0.1545 & 0.0356 & 0.0108 \\
\hline & & $\mathrm{S}_{2}$ & $\mathrm{P}$ & $\mathrm{F}$ & $\mathrm{P}$ & $\mathrm{F}$ & 0.4045 & 0.0233 & 0.0067 \\
\hline & & $\mathrm{S}_{3}$ & $\mathrm{~F}$ & $\mathrm{~F}$ & $\mathrm{~F}$ & $\mathrm{G}$ & 0.5477 & 0.0265 & 0.0059 \\
\hline & & $\mathrm{S}_{4}$ & $\mathrm{G}$ & VG & $\mathrm{G}$ & $\mathrm{F}$ & 0.7205 & 0.0410 & 0.0090 \\
\hline & & $\mathrm{S}_{5}$ & VG & VG & $\mathrm{G}$ & $\mathrm{F}$ & 0.7977 & 0.0356 & 0.0103 \\
\hline & \multirow{5}{*}{$\mathrm{C}_{33}(+)$} & $\mathrm{S}_{1}$ & $\mathrm{~F}$ & $\mathrm{G}$ & VG & $\mathrm{G}$ & 0.7205 & 0.0233 & 0.0090 \\
\hline & & $\mathrm{S}_{2}$ & $\mathrm{G}$ & $\mathrm{F}$ & $\mathrm{F}$ & $\mathrm{F}$ & 0.5477 & 0.0265 & 0.0059 \\
\hline & & $\mathrm{S}_{3}$ & $\mathrm{P}$ & $\mathrm{F}$ & $\mathrm{P}$ & $\mathrm{F}$ & 0.4045 & 0.0410 & 0.0067 \\
\hline & & $\mathrm{S}_{4}$ & $\mathrm{~F}$ & $\mathrm{G}$ & VG & VG & 0.7977 & 0.0356 & 0.0103 \\
\hline & & $\mathrm{S}_{5}$ & $\mathrm{G}$ & $\mathrm{F}$ & VG & $\mathrm{G}$ & 0.7205 & 0.0410 & 0.0089 \\
\hline & \multirow{5}{*}{$\mathrm{C}_{34}(+)$} & $\mathrm{S}_{1}$ & G & VG & $\mathrm{G}$ & $\mathrm{F}$ & 0.7205 & 0.0356 & 0.0090 \\
\hline & & $\mathrm{S}_{2}$ & $\mathrm{~F}$ & $\mathrm{~F}$ & $\mathrm{~F}$ & $\mathrm{G}$ & 0.5477 & 0.0233 & 0.0059 \\
\hline & & $\mathrm{S}_{3}$ & $\mathrm{~F}$ & $\mathrm{~F}$ & $\mathrm{P}$ & $\mathrm{P}$ & 0.4045 & 0.0265 & 0.0067 \\
\hline & & $\mathrm{S}_{4}$ & VG & VG & $\mathrm{G}$ & $\mathrm{F}$ & 0.7977 & 0.0410 & 0.0103 \\
\hline & & $\mathrm{S}_{5}$ & $\mathrm{G}$ & VG & VG & $\mathrm{F}$ & 0.7977 & 0.0410 & 0.0103 \\
\hline & \multirow{5}{*}{$\mathrm{C}_{35}(+)$} & $\mathrm{S}_{1}$ & $\mathrm{VG}$ & VG & $G$ & $\mathrm{G}$ & 0.8455 & 0.0428 & 0.0108 \\
\hline & & $\mathrm{S}_{2}$ & VG & $\mathrm{G}$ & $\mathrm{F}$ & $\mathrm{F}$ & 0.6727 & 0.0333 & 0.0084 \\
\hline & & $\mathrm{S}_{3}$ & $\mathrm{G}$ & $\mathrm{G}$ & $\mathrm{F}$ & $\mathrm{F}$ & 0.5955 & 0.0264 & 0.0067 \\
\hline & & $\mathrm{S}_{4}$ & $\mathrm{G}$ & $\mathrm{G}$ & $\mathrm{G}$ & $\mathrm{G}$ & 0.6910 & 0.032 & 0.0080 \\
\hline & & $\mathrm{S}_{5}$ & VG & $\mathrm{G}$ & $\mathrm{F}$ & $\mathrm{F}$ & 0.6727 & 0.0333 & 0.0084 \\
\hline & \multirow{5}{*}{$\mathrm{C}_{36}(+)$} & $\mathrm{S}_{1}$ & $\mathrm{~F}$ & $\mathrm{~F}$ & $\mathrm{~F}$ & $\mathrm{~F}$ & 0.5000 & 0.0195 & 0.0050 \\
\hline & & $\mathrm{S}_{2}$ & VG & VG & $\mathrm{G}$ & $\mathrm{G}$ & 0.8455 & 0.0429 & 0.0107 \\
\hline & & $\mathrm{S}_{3}$ & VG & $\mathrm{G}$ & $\mathrm{F}$ & $\mathrm{F}$ & 0.6727 & 0.0333 & 0.0084 \\
\hline & & $\mathrm{S}_{4}$ & $\mathrm{G}$ & $\mathrm{G}$ & $\mathrm{G}$ & $\mathrm{G}$ & 0.6910 & 0.032 & 0.0080 \\
\hline & & $\mathrm{S}_{5}$ & $\mathrm{G}$ & $\mathrm{G}$ & $\mathrm{F}$ & $\mathrm{F}$ & 0.5955 & 0.0264 & 0.0067 \\
\hline
\end{tabular}


Table 16 Original decision matrix and weighted average Cloud matrix for criterion $\mathrm{C}_{4}$

\begin{tabular}{cccccccccc}
\hline Criterion & Sub-criteria & Green supplier & $\mathrm{E}_{1}$ & $\mathrm{E}_{2}$ & $\mathrm{E}_{3}$ & $\mathrm{E}_{4}$ & \multicolumn{2}{c}{ Weighted average Cloud matrix } \\
\hline & & $\mathrm{S}_{1}$ & $\mathrm{VG}$ & $\mathrm{VG}$ & $\mathrm{VG}$ & $\mathrm{VG}$ & 1 & 0.0515 & 0.0130 \\
& & $\mathrm{~S}_{2}$ & $\mathrm{G}$ & $\mathrm{VG}$ & $\mathrm{VG}$ & $\mathrm{VG}$ & 0.9227 & 0.0474 & 0.0119 \\
& $\mathrm{C}_{41}(+)$ & $\mathrm{S}_{3}$ & $\mathrm{G}$ & $\mathrm{VG}$ & $\mathrm{VG}$ & $\mathrm{G}$ & 0.8455 & 0.0429 & 0.0108 \\
& & $\mathrm{~S}_{4}$ & $\mathrm{~F}$ & $\mathrm{G}$ & $\mathrm{G}$ & $\mathrm{F}$ & 0.5955 & 0.0265 & 0.0067 \\
& & $\mathrm{~S}_{5}$ & $\mathrm{G}$ & $\mathrm{VG}$ & $\mathrm{G}$ & $\mathrm{VG}$ & 0.8455 & 0.0429 & 0.0108 \\
\cline { 3 - 9 } & & $\mathrm{S}_{1}$ & $\mathrm{VP}$ & $\mathrm{P}$ & $\mathrm{F}$ & $\mathrm{F}$ & 0.3272 & 0.0333 & 0.0084 \\
& & $\mathrm{~S}_{2}$ & $\mathrm{VP}$ & $\mathrm{F}$ & $\mathrm{F}$ & $\mathrm{F}$ & 0.3750 & 0.0210 & 0.0078 \\
$\mathrm{C}_{4}$ & $\mathrm{~S}_{3}(+)$ & $\mathrm{P}$ & $\mathrm{F}$ & $\mathrm{F}$ & $\mathrm{G}$ & 0.5000 & 0.0265 & 0.0067 \\
& $\mathrm{C}_{42}(+)$ & $\mathrm{S}_{4}$ & $\mathrm{P}$ & $\mathrm{G}$ & $\mathrm{G}$ & $\mathrm{G}$ & 0.5955 & 0.032 & 0.0080 \\
& & $\mathrm{~S}_{5}$ & $\mathrm{G}$ & $\mathrm{G}$ & $\mathrm{G}$ & $\mathrm{G}$ & 0.6910 & 0.032 & 0.0080 \\
\hline & & $\mathrm{S}_{1}$ & $\mathrm{G}$ & $\mathrm{G}$ & $\mathrm{G}$ & $\mathrm{G}$ & 0.6910 & 0.032 & 0.0080 \\
& & $\mathrm{~S}_{2}$ & $\mathrm{P}$ & $\mathrm{G}$ & $\mathrm{F}$ & $\mathrm{F}$ & 0.5000 & 0.0265 & 0.0067 \\
& & $\mathrm{~S}_{3}$ & $\mathrm{~F}$ & $\mathrm{VP}$ & $\mathrm{F}$ & $\mathrm{VP}$ & 0.2500 & 0.0389 & 0.0098 \\
& & $\mathrm{~S}_{43}(+)$ & $\mathrm{VP}$ & $\mathrm{F}$ & $\mathrm{F}$ & $\mathrm{F}$ & 0.3750 & 0.0310 & 0.0078 \\
& & $\mathrm{~S}_{4}$ & $\mathrm{P}$ & $\mathrm{F}$ & $\mathrm{F}$ & $\mathrm{P}$ & 0.4045 & 0.0265 & 0.0067 \\
\hline
\end{tabular}

Table 17 Original decision matrix and weighted average Cloud matrix for criterion $\mathrm{C}_{5}$

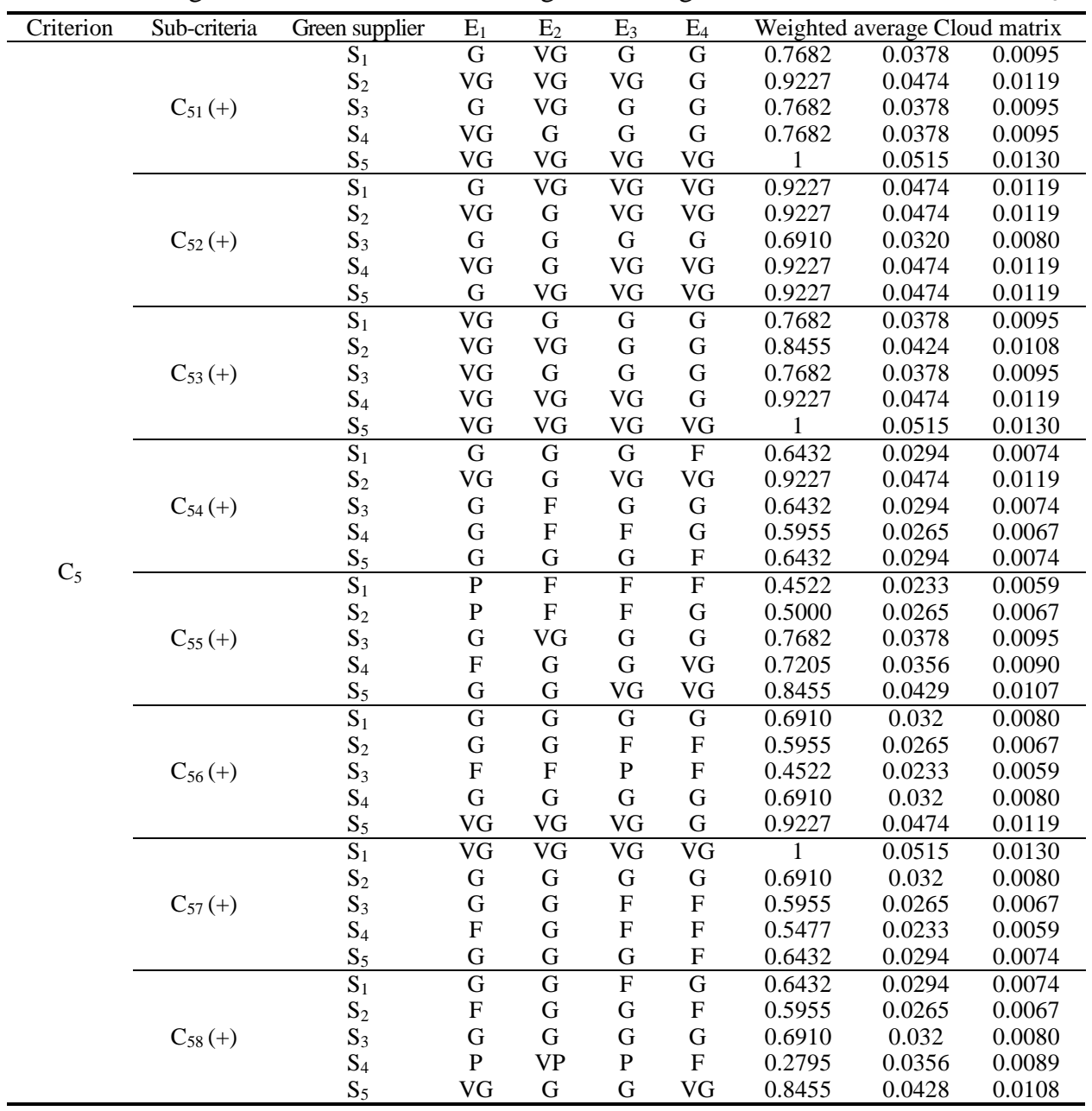


Table 18 Original decision matrix and weighted average Cloud matrix for criterion $\mathrm{C}_{6}$

\begin{tabular}{|c|c|c|c|c|c|c|c|c|c|}
\hline Criterion & Sub-criteria & Green supplier & $E_{1}$ & $E_{2}$ & $\mathrm{E}_{3}$ & $E_{4}$ & Weighte & verage & d matrix \\
\hline \multirow{20}{*}{$\mathrm{C}_{6}$} & \multirow{5}{*}{$\mathrm{C}_{61}(+)$} & $\mathrm{S}_{1}$ & G & $\mathrm{G}$ & $\mathrm{G}$ & G & 0.6910 & 0.032 & 0.0080 \\
\hline & & $\mathrm{S}_{2}$ & G & G & G & G & 0.6910 & 0.032 & 0.0080 \\
\hline & & $\mathrm{S}_{3}$ & VG & VG & VG & G & 0.9227 & 0.0474 & 0.0119 \\
\hline & & $\mathrm{S}_{4}$ & VG & VG & VG & VG & 1 & 0.0515 & 0.0130 \\
\hline & & $\mathrm{S}_{5}$ & VG & VG & VG & VG & 1 & 0.0515 & 0.0130 \\
\hline & \multirow{5}{*}{$\mathrm{C}_{62}(+)$} & $\mathrm{S}_{1}$ & $\mathrm{G}$ & $\bar{G}$ & $\bar{F}$ & $\mathrm{G}$ & 0.6432 & 0.0294 & 0.0074 \\
\hline & & $\mathrm{S}_{2}$ & $\mathrm{P}$ & VP & $\mathrm{F}$ & $\mathrm{F}$ & 0.3272 & 0.0333 & 0.0084 \\
\hline & & $\mathrm{S}_{3}$ & $\mathrm{~F}$ & $\mathrm{~F}$ & $\mathrm{~F}$ & G & 0.5477 & 0.0233 & 0.0057 \\
\hline & & $\mathrm{S}_{4}$ & G & G & G & G & 0.6910 & 0.032 & 0.0080 \\
\hline & & $\mathrm{S}_{5}$ & VG & VG & $\mathrm{G}$ & G & 0.8455 & 0.0429 & 0.0107 \\
\hline & \multirow{5}{*}{$\mathrm{C}_{63}(+)$} & $S_{1}$ & $\mathrm{~F}$ & $\mathrm{~F}$ & $\mathrm{~F}$ & $\mathrm{~F}$ & 0.5000 & 0.0195 & 0.0050 \\
\hline & & $\mathrm{S}_{2}$ & G & $\mathrm{F}$ & $\mathrm{F}$ & $\mathrm{F}$ & 0.5477 & 0.0233 & 0.0059 \\
\hline & & $\mathrm{S}_{3}$ & $\mathrm{G}$ & G & $\mathrm{G}$ & VG & 0.7682 & 0.0378 & 0.0095 \\
\hline & & $\mathrm{S}_{4}$ & VG & VG & VG & VG & 1 & 0.0515 & 0.0130 \\
\hline & & $\mathrm{S}_{5}$ & $\mathrm{P}$ & VP & $\mathrm{F}$ & $\mathrm{F}$ & 0.3272 & 0.0333 & 0.0085 \\
\hline & \multirow{5}{*}{$\mathrm{C}_{64}(+)$} & $S_{1}$ & $\mathrm{G}$ & $\bar{G}$ & $\bar{G}$ & $\mathrm{G}$ & 0.6910 & 0.032 & 0.0080 \\
\hline & & $\mathrm{S}_{2}$ & VG & G & G & G & 0.7682 & 0.0378 & 0.0095 \\
\hline & & $\mathrm{S}_{3}$ & G & VG & G & $\mathrm{G}$ & 0.7682 & 0.0378 & 0.0095 \\
\hline & & $\mathrm{S}_{4}$ & $\mathrm{G}$ & G & VG & VG & 0.8455 & 0.0428 & 0.0108 \\
\hline & & $\mathrm{S}_{5}$ & G & G & G & VG & 0.7682 & 0.0378 & 0.0095 \\
\hline
\end{tabular}

Table 19 Original decision matrix and weighted average Cloud matrix for criterion $\mathrm{C}_{7}$

\begin{tabular}{|c|c|c|c|c|c|c|c|c|c|}
\hline Criterion & Sub-criteria & Green supplier & $E_{1}$ & $\mathrm{E}_{2}$ & $E_{3}$ & $E_{4}$ & Weighted & erage $\mathrm{C}$ & d matrix \\
\hline \multirow{15}{*}{$\mathrm{C}_{7}$} & \multirow{5}{*}{$\mathrm{C}_{71}(+)$} & $\mathrm{S}_{1}$ & $\mathrm{G}$ & $\mathrm{G}$ & $\mathrm{G}$ & G & 0.6910 & 0.032 & 0.0080 \\
\hline & & $\mathrm{S}_{2}$ & G & G & G & $\mathrm{F}$ & 0.6432 & 0.0294 & 0.0074 \\
\hline & & $\mathrm{S}_{3}$ & $\mathrm{~F}$ & $\mathrm{~F}$ & G & $\mathrm{F}$ & 0.5477 & 0.0233 & 0.0059 \\
\hline & & $\mathrm{S}_{4}$ & G & G & G & VG & 0.7682 & 0.0378 & 0.0095 \\
\hline & & $\mathrm{S}_{5}$ & VG & VG & VG & G & 0.9227 & 0.0474 & 0.0119 \\
\hline & \multirow{5}{*}{$\mathrm{C}_{72}(+)$} & $S_{1}$ & $\mathrm{~F}$ & $\mathrm{~F}$ & G & G & 0.5955 & 0.0265 & 0.0067 \\
\hline & & $\mathrm{S}_{2}$ & G & $\mathrm{F}$ & $\mathrm{G}$ & $\mathrm{F}$ & 0.5955 & 0.0265 & 0.0067 \\
\hline & & $\mathrm{S}_{3}$ & G & G & $\mathrm{G}$ & G & 0.6910 & 0.032 & 0.0080 \\
\hline & & $\mathrm{S}_{4}$ & VG & G & VG & VG & 0.9227 & 0.0474 & 0.0119 \\
\hline & & $\mathrm{S}_{5}$ & G & G & VG & VG & 0.8455 & 0.0429 & 0.0107 \\
\hline & \multirow{5}{*}{$\mathrm{C}_{73}(+)$} & $\overline{S_{1}}$ & VG & VG & $\mathrm{G}$ & G & 0.8455 & 0.0429 & 0.0107 \\
\hline & & $\mathrm{S}_{2}$ & G & VG & G & VG & 0.8455 & 0.0429 & 0.0107 \\
\hline & & $\mathrm{S}_{3}$ & G & G & $\mathrm{G}$ & G & 0.6910 & 0.0320 & 0.0080 \\
\hline & & $\mathrm{S}_{4}$ & G & G & $\mathrm{F}$ & G & 0.6432 & 0.0294 & 0.0074 \\
\hline & & $\mathrm{S}_{5}$ & G & $\mathrm{F}$ & G & $\mathrm{F}$ & 0.5955 & 0.0265 & 0.0067 \\
\hline
\end{tabular}


Table 20 Original decision matrix and weighted average Cloud matrix for criterion $\mathrm{C}_{8}$

\begin{tabular}{|c|c|c|c|c|c|c|c|c|c|}
\hline Criterion & Sub-criteria & Green supplier & $\overline{E_{1}}$ & $\mathrm{E}_{2}$ & $\mathrm{E}_{3}$ & $\mathrm{E}_{4}$ & Weighte & verage C & d matrix \\
\hline \multirow{20}{*}{$\mathrm{C}_{8}$} & \multirow{5}{*}{$\mathrm{C}_{81}(+)$} & $\mathrm{S}_{1}$ & $\mathrm{G}$ & VG & G & $\mathrm{G}$ & 0.7682 & 0.0378 & 0.0095 \\
\hline & & $S_{2}$ & $\mathrm{G}$ & $\mathrm{F}$ & $\mathrm{F}$ & $\mathrm{G}$ & 0.5955 & 0.0265 & 0.0067 \\
\hline & & $\mathrm{S}_{3}$ & G & VG & G & VG & 0.8455 & 0.0429 & 0.0107 \\
\hline & & $\mathrm{S}_{4}$ & G & VG & VG & VG & 0.9227 & 0.0474 & 0.0119 \\
\hline & & $\mathrm{S}_{5}$ & VG & VG & VG & $\mathrm{G}$ & 0.9227 & 0.0474 & 0.0119 \\
\hline & \multirow{5}{*}{$\mathrm{C}_{82}(+)$} & $\overline{S_{1}}$ & $F$ & $\mathrm{~F}$ & $\bar{F}$ & $\overline{\mathrm{P}}$ & 0.4522 & 0.0233 & 0.0059 \\
\hline & & $\mathrm{S}_{2}$ & VG & G & VG & VG & 0.9227 & 0.0474 & 0.0119 \\
\hline & & $\mathrm{S}_{3}$ & G & G & G & G & 0.6910 & 0.032 & 0.0080 \\
\hline & & $\mathrm{S}_{4}$ & VG & G & VG & $\mathrm{G}$ & 0.8455 & 0.0429 & 0.0108 \\
\hline & & $\mathrm{S}_{5}$ & VG & VG & VG & $\mathrm{G}$ & 0.9227 & 0.0474 & 0.0119 \\
\hline & \multirow{5}{*}{$\mathrm{C}_{83}(+)$} & $S_{1}$ & VG & VG & VG & VG & 1 & 0.0515 & 0.0130 \\
\hline & & $\mathrm{S}_{2}$ & G & VG & VG & G & 0.8455 & 0.0429 & 0.0108 \\
\hline & & $\mathrm{S}_{3}$ & VG & VG & VG & VG & 1 & 0.0515 & 0.0130 \\
\hline & & $\mathrm{S}_{4}$ & VG & G & G & VG & 0.8455 & 0.0429 & 0.0108 \\
\hline & & $S_{5}$ & $\mathrm{G}$ & G & $\mathrm{F}$ & $\mathrm{G}$ & 0.6432 & 0.0294 & 0.0074 \\
\hline & \multirow{5}{*}{$\mathrm{C}_{84}(+)$} & $\overline{S_{1}}$ & VG & VG & $\mathrm{G}$ & VG & 0.9227 & 0.0474 & 0.0119 \\
\hline & & $\mathrm{S}_{2}$ & VG & G & VG & G & 0.8455 & 0.0429 & 0.0108 \\
\hline & & $\mathrm{S}_{3}$ & G & VG & VG & $\mathrm{G}$ & 0.8455 & 0.0429 & 0.0108 \\
\hline & & $\mathrm{S}_{4}$ & $\mathrm{~F}$ & $\mathrm{~F}$ & $\mathrm{~F}$ & $\mathrm{G}$ & 0.5477 & 0.0233 & 0.0059 \\
\hline & & $\mathrm{S}_{5}$ & VG & G & G & $\mathrm{F}$ & 0.7205 & 0.0356 & 0.0089 \\
\hline
\end{tabular}

Table 21 Original decision matrix and weighted average Cloud matrix for criterion $\mathrm{C}_{9}$

\begin{tabular}{|c|c|c|c|c|c|c|c|c|c|}
\hline Criterion & Sub-criteria & $\begin{array}{l}\text { Green } \\
\text { supplier }\end{array}$ & $\mathrm{E}_{1}$ & $\mathrm{E}_{2}$ & $E_{3}$ & $\mathrm{E}_{4}$ & \multicolumn{3}{|c|}{ Weighted average Cloud matrix } \\
\hline \multirow{25}{*}{$\mathrm{C}_{9}$} & \multirow{5}{*}{$\mathrm{C}_{91}(-)$} & $\mathrm{S}_{1}$ & $\mathrm{H}$ & $\mathrm{H}$ & $\mathrm{VH}$ & $\mathrm{H}$ & 0.7682 & 0.0378 & 0.0095 \\
\hline & & $\mathrm{S}_{2}$ & M & $\mathrm{H}$ & M & M & 0.5477 & 0.0233 & 0.0059 \\
\hline & & $\mathrm{S}_{3}$ & $\mathrm{M}$ & $\mathrm{H}$ & $\mathrm{H}$ & M & 0.5955 & 0.0265 & 0.0067 \\
\hline & & $\mathrm{S}_{4}$ & $\mathrm{~L}$ & VL & $\mathrm{M}$ & $\mathrm{L}$ & 0.2795 & 0.0356 & 0.0090 \\
\hline & & $\mathrm{S}_{5}$ & $\mathrm{~L}$ & $\mathrm{M}$ & $\mathrm{M}$ & $\mathrm{L}$ & 0.4045 & 0.0265 & 0.0067 \\
\hline & \multirow{5}{*}{$\mathrm{C}_{92}(-)$} & $\mathrm{S}_{1}$ & $\mathrm{~L}$ & $\mathrm{~L}$ & $\mathrm{M}$ & $\mathrm{M}$ & 0.4045 & 0.0265 & 0.0067 \\
\hline & & $\mathrm{S}_{2}$ & $\mathrm{~L}$ & M & $\mathrm{M}$ & M & 0.4522 & 0.0233 & 0.0059 \\
\hline & & $\mathrm{S}_{3}$ & VL & M & $\mathrm{M}$ & $\mathrm{L}$ & 0.3272 & 0.0333 & 0.0084 \\
\hline & & $\mathrm{S}_{4}$ & $\mathrm{~L}$ & $\mathrm{~L}$ & $\mathrm{H}$ & M & 0.4522 & 0.0294 & 0.0074 \\
\hline & & $\mathrm{S}_{5}$ & $\mathrm{~L}$ & $\mathrm{~L}$ & M & $\mathrm{L}$ & 0.3567 & 0.0294 & 0.0074 \\
\hline & \multirow{5}{*}{$\mathrm{C}_{93}(-)$} & $\mathrm{S}_{1}$ & $\mathrm{H}$ & $\mathrm{H}$ & $\mathrm{H}$ & $\mathrm{H}$ & 0.6910 & 0.032 & 0.0080 \\
\hline & & $\mathrm{S}_{2}$ & $\mathrm{H}$ & $\mathrm{H}$ & $\mathrm{M}$ & $\mathrm{M}$ & 0.5955 & 0.0265 & 0.0067 \\
\hline & & $\mathrm{S}_{3}$ & M & M & $\mathrm{M}$ & $\mathrm{H}$ & 0.5477 & 0.0233 & 0.0059 \\
\hline & & $\mathrm{S}_{4}$ & M & $\mathrm{H}$ & $\mathrm{H}$ & $\mathrm{M}$ & 0.5955 & 0.0265 & 0.0067 \\
\hline & & $\mathrm{S}_{5}$ & $\mathrm{H}$ & $\mathrm{H}$ & $\mathrm{H}$ & $\mathrm{H}$ & 0.6910 & 0.0320 & 0.0080 \\
\hline & \multirow{5}{*}{$\mathrm{C}_{94}(-)$} & $\mathrm{S}_{1}$ & $\mathrm{H}$ & $\mathrm{VH}$ & $\mathrm{H}$ & $\mathrm{H}$ & 0.7682 & 0.0378 & 0.0095 \\
\hline & & $\mathrm{S}_{2}$ & $\mathrm{H}$ & M & $\mathrm{M}$ & $\mathrm{H}$ & 0.5955 & 0.0265 & 0.0067 \\
\hline & & $\mathrm{S}_{3}$ & $\mathrm{H}$ & M & $\mathrm{H}$ & $\mathrm{M}$ & 0.5955 & 0.0265 & 0.0067 \\
\hline & & $\mathrm{S}_{4}$ & VL & VL & $\mathrm{L}$ & M & 0.2022 & 0.041 & 0.0103 \\
\hline & & $\mathrm{S}_{5}$ & $\mathrm{M}$ & $\mathrm{L}$ & $\mathrm{L}$ & $\mathrm{M}$ & 0.4045 & 0.0265 & 0.0067 \\
\hline & \multirow{5}{*}{$\mathrm{C}_{95}(-)$} & $\mathrm{S}_{1}$ & $\mathrm{M}$ & $\mathrm{H}$ & $\mathrm{M}$ & $\mathrm{H}$ & 0.5955 & 0.0265 & 0.0067 \\
\hline & & $\mathrm{S}_{2}$ & $\mathrm{~L}$ & VL & $\mathrm{L}$ & $\mathrm{M}$ & 0.2795 & 0.0356 & 0.0090 \\
\hline & & $\mathrm{S}_{3}$ & $\mathrm{M}$ & $\mathrm{L}$ & M & M & 0.4522 & 0.0233 & 0.0059 \\
\hline & & $\mathrm{S}_{4}$ & $\mathrm{~L}$ & VL & M & $\mathrm{L}$ & 0.2795 & 0.0356 & 0.0090 \\
\hline & & $\mathrm{S}_{5}$ & $\mathrm{H}$ & $\mathrm{H}$ & $\mathrm{H}$ & $\mathrm{M}$ & 0.6432 & 0.0294 & 0.0074 \\
\hline
\end{tabular}


Table 22 Original decision matrix and weighted average Cloud matrix for criterion $\mathrm{C}_{10}$

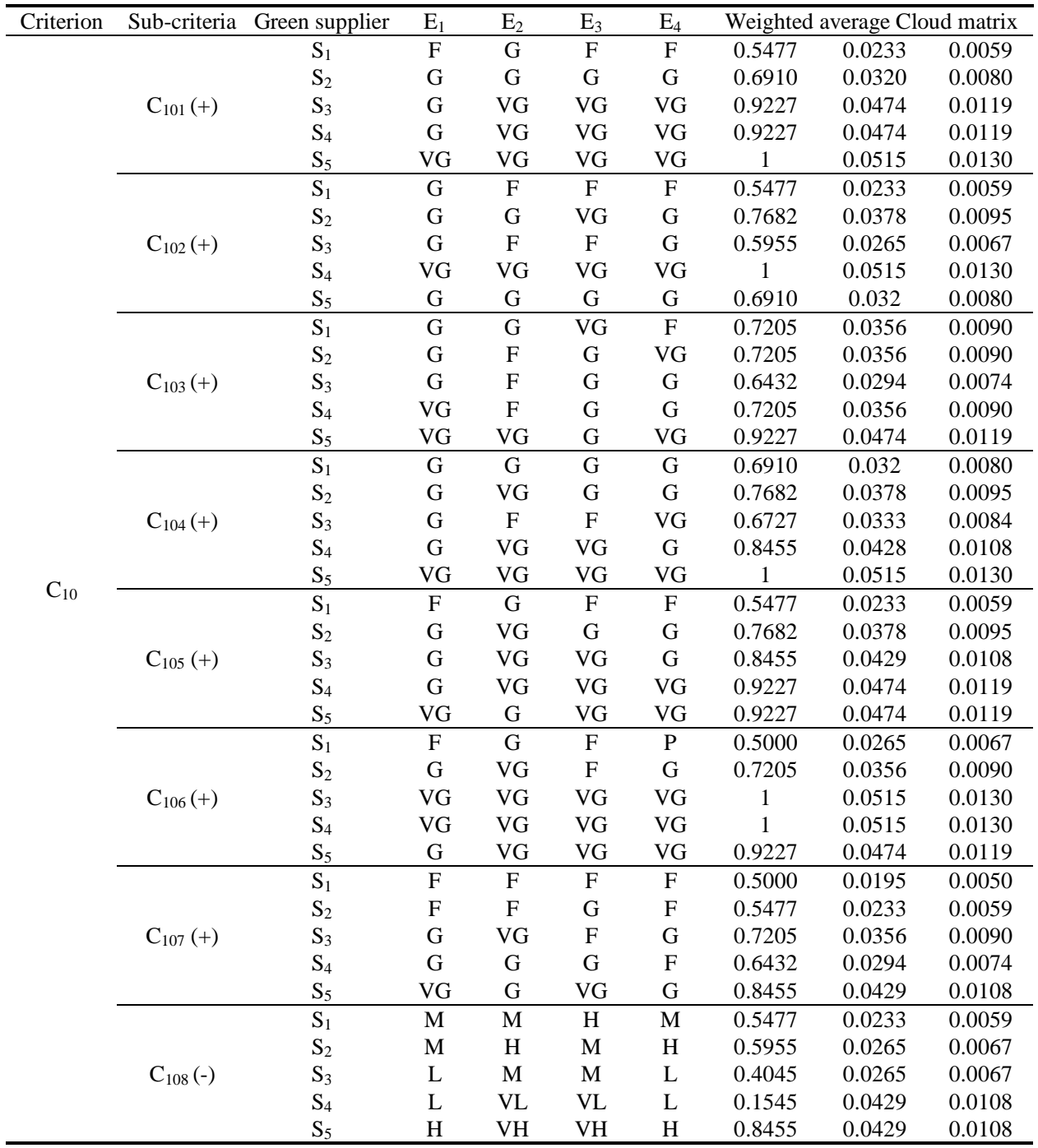


Table 23 Original decision matrix and weighted average Cloud matrix for criterion $\mathrm{C}_{11}$

\begin{tabular}{|c|c|c|c|c|c|c|c|c|c|}
\hline \multirow[t]{2}{*}{ Criterion } & \multirow[t]{2}{*}{ Sub-criteria } & \multirow{2}{*}{$\begin{array}{c}\begin{array}{c}\text { Green } \\
\text { supplier }\end{array} \\
S_{1}\end{array}$} & \multirow{2}{*}{$\begin{array}{c}E_{1} \\
G\end{array}$} & \multirow{2}{*}{$\begin{array}{c}E_{2} \\
G\end{array}$} & \multirow{2}{*}{$\frac{\mathrm{E}_{3}}{\mathrm{VG}}$} & \multirow{2}{*}{$\begin{array}{l}\mathrm{E}_{4} \\
\mathrm{VG}\end{array}$} & \multicolumn{3}{|c|}{ Weighted average Cloud matrix } \\
\hline & & & & & & & 0.8455 & 0.0429 & 0.0108 \\
\hline \multirow{24}{*}{$\mathrm{C}_{11}$} & \multirow{4}{*}{$\mathrm{C}_{111}(+)$} & $\mathrm{S}_{2}$ & F & G & VG & G & 0.7205 & 0.0356 & 0.0090 \\
\hline & & $\mathrm{S}_{3}$ & G & VG & VG & VG & 0.9227 & 0.0474 & 0.0119 \\
\hline & & $\mathrm{S}_{4}$ & G & $\mathrm{G}$ & VG & VG & 0.8455 & 0.0428 & 0.0108 \\
\hline & & $\mathrm{S}_{5}$ & VG & VG & VG & G & 0.9227 & 0.0474 & 0.0119 \\
\hline & \multirow{5}{*}{$\mathrm{C}_{112}(+)$} & $\mathrm{S}_{1}$ & VG & $\mathrm{G}$ & $\mathrm{G}$ & $\mathrm{G}$ & 0.7682 & 0.0378 & 0.095 \\
\hline & & $\mathrm{S}_{2}$ & $\mathrm{G}$ & VG & VG & VG & 0.9227 & 0.0474 & 0.0119 \\
\hline & & $\mathrm{S}_{3}$ & VG & VG & VG & VG & 1 & 0.0515 & 0.0130 \\
\hline & & $\mathrm{S}_{4}$ & VG & VG & $\mathrm{G}$ & VG & 0.9227 & 0.0474 & 0.0119 \\
\hline & & $\mathrm{S}_{5}$ & VG & VG & VG & $\mathrm{G}$ & 0.9227 & 0.0474 & 0.0119 \\
\hline & \multirow{5}{*}{$\mathrm{C}_{113}(+)$} & $\mathrm{S}_{1}$ & G & G & $\mathrm{F}$ & $\mathrm{G}$ & 0.6432 & 0.0294 & 0.0074 \\
\hline & & $\mathrm{S}_{2}$ & G & G & G & $\mathrm{F}$ & 0.6432 & 0.0294 & 0.0074 \\
\hline & & $\mathrm{S}_{3}$ & $\mathrm{~F}$ & G & G & G & 0.6432 & 0.0294 & 0.0074 \\
\hline & & $\mathrm{S}_{4}$ & VG & VG & G & G & 0.8455 & 0.0429 & 0.0108 \\
\hline & & $\mathrm{S}_{5}$ & G & G & G & VG & 0.7682 & 0.0378 & 0.0095 \\
\hline & \multirow{5}{*}{$\mathrm{C}_{114}(+)$} & $\overline{S_{1}}$ & $F$ & F & $\mathrm{G}$ & $\mathrm{F}$ & 0.5477 & 0.0233 & 0.0059 \\
\hline & & $\mathrm{S}_{2}$ & $\mathrm{P}$ & VP & $\mathrm{F}$ & $\mathrm{P}$ & 0.2795 & 0.0356 & 0.0090 \\
\hline & & $\mathrm{S}_{3}$ & $\mathrm{P}$ & VP & VP & $\mathrm{P}$ & 0.1545 & 0.0429 & 0.0108 \\
\hline & & $\mathrm{S}_{4}$ & VG & VG & $\mathrm{G}$ & G & 0.8455 & 0.0429 & 0.0108 \\
\hline & & $\mathrm{S}_{5}$ & VG & VG & VG & VG & 1 & 0.0515 & 0.0130 \\
\hline & \multirow{5}{*}{$\mathrm{C}_{115}(+)$} & $\mathrm{S}_{1}$ & G & $\mathrm{F}$ & $\mathrm{F}$ & $\mathrm{F}$ & 0.5477 & 0.0233 & 0.0059 \\
\hline & & $\mathrm{S}_{2}$ & G & G & VG & G & 0.7682 & 0.0378 & 0.0095 \\
\hline & & $\mathrm{S}_{3}$ & G & F & $\mathrm{F}$ & G & 0.5955 & 0.0265 & 0.0067 \\
\hline & & $\mathrm{S}_{4}$ & VG & VG & VG & VG & 1 & 0.0515 & 0.0130 \\
\hline & & $\mathrm{S}_{5}$ & G & $\mathrm{G}$ & $\mathrm{G}$ & G & 0.6910 & 0.032 & 0.0080 \\
\hline
\end{tabular}

Table 24 Original decision matrix and weighted average Cloud matrix for criterion $\mathrm{C}_{12}$

\begin{tabular}{|c|c|c|c|c|c|c|c|c|c|}
\hline \multirow{2}{*}{ Criterion } & \multirow[t]{2}{*}{ Sub-criteria } & \multirow{2}{*}{$\begin{array}{c}\begin{array}{c}\text { Green } \\
\text { supplier }\end{array} \\
\mathrm{S}_{1}\end{array}$} & \multirow{2}{*}{$\frac{E_{1}}{G}$} & \multirow{2}{*}{$\frac{E_{2}}{G}$} & \multirow{2}{*}{$\frac{E_{3}}{G}$} & \multirow{2}{*}{$\frac{\mathrm{E}_{4}}{\mathrm{G}}$} & \multicolumn{3}{|c|}{ Weighted average Cloud matrix } \\
\hline & & & & & & & 0.6910 & 0.032 & 0.0080 \\
\hline \multirow{19}{*}{$\mathrm{C}_{12}$} & \multirow{4}{*}{$\mathrm{C}_{121}(+)$} & $\mathrm{S}_{2}$ & $\mathrm{G}$ & VG & G & G & 0.7682 & 0.0378 & 0.0095 \\
\hline & & $\mathrm{S}_{3}$ & $\mathrm{G}$ & $\mathrm{F}$ & $\mathrm{F}$ & VG & 0.6727 & 0.0333 & 0.0084 \\
\hline & & $\mathrm{S}_{4}$ & $\mathrm{G}$ & VG & VG & $\mathrm{G}$ & 0.8455 & 0.0428 & 0.0108 \\
\hline & & $\mathrm{S}_{5}$ & VG & VG & VG & VG & 1 & 0.0515 & 0.0130 \\
\hline & \multirow{5}{*}{$\mathrm{C}_{122}(+)$} & $\mathrm{S}_{1}$ & VG & VG & VG & $\mathrm{G}$ & 0.9227 & 0.0474 & 0.0119 \\
\hline & & $\mathrm{S}_{2}$ & VG & VG & $\mathrm{G}$ & VG & 0.9227 & 0.0474 & 0.0119 \\
\hline & & $\mathrm{S}_{3}$ & $\mathrm{G}$ & G & G & $\mathrm{F}$ & 0.6432 & 0.0294 & 0.0074 \\
\hline & & $\mathrm{S}_{4}$ & $\mathrm{~F}$ & $\mathrm{G}$ & $\mathrm{F}$ & $\mathrm{G}$ & 0.5955 & 0.0265 & 0.0067 \\
\hline & & $\mathrm{S}_{5}$ & $\mathrm{VG}$ & VG & $\mathrm{G}$ & $\mathrm{G}$ & 0.8455 & 0.0429 & 0.0108 \\
\hline & \multirow{5}{*}{$\mathrm{C}_{123}(+)$} & $\mathrm{S}_{1}$ & $\mathrm{G}$ & VG & G & $\mathrm{F}$ & 0.7205 & 0.0356 & 0.0090 \\
\hline & & $\mathrm{S}_{2}$ & VG & $\mathrm{G}$ & VG & G & 0.8455 & 0.0429 & 0.0108 \\
\hline & & $\mathrm{S}_{3}$ & $\mathrm{G}$ & VG & VG & VG & 0.9227 & 0.0474 & 0.0119 \\
\hline & & $\mathrm{S}_{4}$ & VG & VG & $\mathrm{G}$ & $\mathrm{G}$ & 0.8455 & 0.0429 & 0.0108 \\
\hline & & $\mathrm{S}_{5}$ & $\mathrm{G}$ & G & G & G & 0.6910 & 0.032 & 0.0080 \\
\hline & \multirow{5}{*}{$\mathrm{C}_{124}(+)$} & $S_{1}$ & VG & VG & VG & VG & 1 & 0.0515 & 0.0130 \\
\hline & & $\mathrm{S}_{2}$ & $\mathrm{G}$ & G & G & G & 0.6910 & 0.0320 & 0.0080 \\
\hline & & $\mathrm{S}_{3}$ & $\mathrm{~F}$ & F & G & G & 0.5955 & 0.0265 & 0.0067 \\
\hline & & $\mathrm{S}_{4}$ & $\mathrm{G}$ & $\mathrm{F}$ & G & G & 0.6432 & 0.0294 & 0.0074 \\
\hline & & $\mathrm{S}_{5}$ & $\mathrm{G}$ & VG & $\mathrm{G}$ & VG & 0.8455 & 0.0429 & 0.0108 \\
\hline
\end{tabular}


In order to validate the solution accuracy and reliability of the ranking results as derived using the Cloud TOPSIS model, the same green supplier selection problem is again solved while employing three other variants of the TOPSIS method, i.e. original TOPSIS, fuzzy TOPSIS and interval TOPSIS. The corresponding rankings of the five green suppliers are provided in Table 25. It can be interestingly revealed that for all the four different TOPSIS models, green supplier $S_{4}$ is the best choice and $S_{1}$ is the worst choice for the considered automobile manufacturing unit. There are slight variations in the intermediate rankings for the adopted approaches which can only be attributed to the difference in the mathematical complexities involved in these methods.

Table 25 Rankings of the green suppliers

\begin{tabular}{|c|c|c|c|c|c|c|c|}
\hline \multirow{2}{*}{$\begin{array}{c}\text { Green } \\
\text { supplier }\end{array}$} & \multicolumn{4}{|c|}{ Cloud TOPSIS model } & \multirow{2}{*}{ TOPSIS } & \multirow{2}{*}{$\begin{array}{c}\text { Fuzzy } \\
\text { TOPSIS }\end{array}$} & \multirow{2}{*}{$\begin{array}{l}\text { Interval } \\
\text { TOPSIS }\end{array}$} \\
\hline & $d\left(A_{i}, \mathrm{~A}^{+}\right)$ & $d\left(A_{i}, \mathrm{~A}^{-}\right)$ & $f_{i}$ & Rank & & & \\
\hline $\mathrm{S}_{1}$ & 0.0438 & 0.0362 & 0.4529 & 5 & 5 & 5 & 5 \\
\hline $\mathrm{S}_{2}$ & 0.0435 & 0.0402 & 0.4807 & 2 & 4 & 4 & 3 \\
\hline $\mathrm{S}_{3}$ & 0.0435 & 0.0396 & 0.4763 & 4 & 3 & 3 & 4 \\
\hline $\mathrm{S}_{4}$ & 0.0403 & 0.0378 & 0.4842 & 1 & 1 & 1 & 1 \\
\hline $\mathrm{S}_{5}$ & 0.0399 & 0.0368 & 0.4797 & 3 & 2 & 2 & 2 \\
\hline
\end{tabular}

\section{CONCLUSIONS}

In this paper, the Cloud TOPSIS model is applied to identify the best performing green supplier in an automobile manufacturing unit. The TOPSIS method has already become popular as an effective MCDM tool due to its various added advantages. But, the TOPSIS method along with its other variants, like fuzzy TOPSIS and interval TOPSIS cannot solve MCDM problems where both fuzziness and randomness are present in the information acquired from different experts while expressing their opinions with respect to the performance of the participating green suppliers in a manufacturing unit. The Cloud model is integrated here with the TOPSIS method to deal with this problem arising in a group decision-making environment. The integrated model attempts to quantify the qualitative assessment of the green suppliers by the experts while accounting for the fuzziness and randomness inherent in the decisionmaking procedure. Five green supplies are considered in a demonstrative example to be appraised by four experts with respect to 12 evaluation criteria (59 sub-criteria). This model identifies green supplier $\mathrm{S}_{4}$ as the best choice. The derived ranking results using the adopted model closely match with those obtained from the other variants of the TOPSIS method. Thus, it can be effectively applied to solving real time group decision-making problems with its better distinction ability. But, it has also few drawbacks like its inability to consider the interactions between different criteria present in the evaluation process, unsuitability to deal with welldefined non-random processes, complexity in the calculations involved, etc. Hence, it is advised to develop a software prototype (decision support system) to take care of the varied fuzzy and random opinions of the experts while arriving at the final green supplier selection decision. 


\section{REFERENCES}

1. Gurel, O., Acar, A.Z., Onden, I., Gumus, I., 2015, Determinants of the green supplier selection, Procedia Social and Behavioral Sciences, 181, pp. 131-139.

2. Govindan, K., Rajendran, S., Sarkis, J., Murugesan, P., 2015, Multi criteria decision making approaches for green supplier evaluation and selection: a literature review, Journal of Cleaner Production, 98, pp. 66-83.

3. Kuo, R.J., Wang, Y.C., Tien, F.C., 2010, Integration of artificial neural network and MADA methods for green supplier selection, Journal of Cleaner Production, 18, pp. 1161-1170.

4. Ashlaghi, M.J., 2014, A new approach to green supplier selection based on fuzzy multi-criteria decision making method and linear physical programming, Tehnički Vjesnik, 21(3), pp. 591-597.

5. Dobos, I., Vörösmarty, G., 2014, Green supplier selection and evaluation using DEA-type composite indicators, International Journal of Production Economics, 157, pp. 273-278.

6. Yazdani, M., 2014, An integrated MCDM approach to green supplier selection, International Journal of Industrial Engineering Computations, 5, pp. 443-458.

7. Cao, Q., Wu, J., Liang, C., 2015, An intuitionsitic fuzzy judgement matrix and TOPSIS integrated multicriteria decision making method for green supplier selection, Journal of Intelligent \& Fuzzy Systems, 28(1), pp. 117-126.

8. Hashemi, S.H., Karimi, A., Tavana, M., 2015, An integrated green supplier selection approach with analytic network process and improved grey relational analysis, International Journal of Production Economics, 157, pp. 178-191.

9. Chen, H.M.W., Chou, S-Y., Luu, Q.D., Yu, T.H-K., 2016, A fuzzy MCDM approach for green supplier selection from the economic and environmental aspects, Mathematical Problems in Engineering, Article ID 8097386, 10 pages, http://dx.doi.org/10.1155/2016/8097386.

10. Doğan, A., Söylemez, İ., Özcan, U., 2016, Green supplier selection by using fuzzy TOPSIS method, World Scientific Proceedings Series on Computer Engineering and Information Science, pp. 638-645.

11. Ghorabaee, M.K., Zavadskas, E.K., Amiri, M., Esmaeili, A., 2016, Multi-criteria evaluation of green suppliers using an extended WASPAS method with interval type-2 fuzzy sets, Journal of Cleaner Production, 137, pp. 213-229.

12. Watróbski, J., Sałabun, W., 2016. Green supplier selection framework based on multi-criteria decision-analysis approach, In: Proceedings of the International Conference on Sustainable Design and Manufacturing, Springer, pp. 361-371.

13. Yu, Q., Hou, F., 2016, An approach for green supplier selection in the automobile manufacturing industry, Kybernetes, 45(4), pp. 571-588.

14. Sahu, A.K., Datta, S., Mahapatra, S.S., 2016, Evaluation and selection of suppliers considering green perspectives: Comparative analysis on application of FMLMCDM and fuzzy-TOPSIS, Benchmarking: An International Journal, 23(6), pp. 1579-1604.

15. Yazdani, M., Zolfani, S.H., Zavadskas, E.K., 2016, New integration of MCDM methods and QFD in the selection of green suppliers, Journal of Business Economics and Management, 17(6), pp. 1097-1113.

16. Gavareshki, M.H.K., Hosseini, S.J., Khajezadeh, M., 2017, A case study of green supplier selection method using an integrated ISM-fuzzy MICMAC analysis and multi-criteria decision making, Industrial Engineering \& Management Systems, 16(4), pp. 562-573.

17. Hashemzahi, P., Musa, S.N., Yusof, F., 2017, A hybrid fuzzy multi-criteria decision making model for green supplier selection, Journal of Fundamental and Applied Sciences, 9, pp. 417-429.

18. Qin, J., Liu, X., Pedrycz, W., 2017, An extended TODIM multi-criteria group decision making method for green supplier selection in interval type-2 fuzzy environment, European Journal of Operational Research, 258, pp. 626-638.

19. Shafique, M.N., 2017, Developing the hybrid multi criteria decision making approach for green supplier evaluation, In: Proceedings of the International Conference on Next Generation Computing Technologies, Singapore, pp. 162-175.

20. Wang, K-Q., Liu, H-C., Liu, L., Huang, J., 2017, Green supplier evaluation and selection using cloud model theory and the QUALIFLEX method, Sustainability, 9, 17 pages, doi:10.3390/su9050688.

21. Badi, I. A., Abdulshahed, A. M., Shetwan, A. G., 2018, A case study of supplier selection for a steelmaking company in Libya by using the combinative distance-based assessment (CODAS) model, Decision Making: Applications in Management and Engineering, 1(1), pp. 1-12

22. Banaeian, N., Mobli, H., Fahimnia, B., Nielsen, I.E., Omid, M., 2018, Green supplier selection using fuzzy group decision making methods: A case study from the agri-food industry, Computers and Operations Research, 89, pp. 337-347. 
23. Zhu, J., Li, Y., 2018, Green supplier selection based on consensus process and integrating prioritized operator and Choquet integral, Sustainability, 10, 22 pages, doi:10.3390/su10082744.

24. Abdullah, L., Chan, W., Afshari, A., 2019, Application of PROMETHEE method for green supplier selection: a comparative result based on preference functions, Journal of Industrial Engineering International, 15, pp. 271-285.

25. Alguliyev, R., Aliguliyev, R., Yusifov, F., 2019, Multi-criteria evaluation + The positional approach to candidate selection in e-voting, Decision Making: Applications in Management and Engineering, 2(2), pp. $65-80$.

26. Biswas, S., Bandyopadhyay, G., Guha, B., Bhattacharjee, M., 2019, An ensemble approach for portfolio selection in a multi-criteria decision making framework, Decision Making: Applications in Management and Engineering, 2(2), pp. 138-158.

27. Chatterjee, P., Stević, Ž., 2019, A two-phase fuzzy AHP-fuzzy TOPSIS model for supplier evaluation in manufacturing environment, Operational Research in Engineering Sciences: Theory and Applications, 2(1), pp. 72-90.

28. Durmić, E., 2019, The evaluation of the criteria for sustainable supplier selection by using the FUCOM method, Operational Research in Engineering Sciences: Theory and Applications, 2(1), pp. 91-107.

29. Liu, Y., Jin, L., Zhu, F., 2019, A multi-criteria group decision making model for green supplier selection under the ordered weighted hesitant fuzzy environment, Symmetry, 11, 16 pages, doi:10.3390/sym11010017.

30. Lu, Z., Sun, X., Wang, Y., Xu, C., 2019, Green supplier selection in straw biomass industry based on cloud model and possibility degree, Journal of Cleaner Production, 209, pp. 995-1005.

31. Rashidi, K., Cullinane, K., 2019, A comparison of fuzzy DEA and fuzzy TOPSIS in sustainable supplier selection: Implications for sourcing strategy, Expert Systems with Applications, 121, pp. 266-281.

32. Yu, C., Shao, Y., Wang, K., Zhang, L., 2019, A group decision making sustainable supplier selection approach using extended TOPSIS under interval-valued Pythagorean fuzzy environment, Expert Systems with Applications, 121, pp. 1-17.

33. Yucesan, M., Mete, S., Serin, F., Celik, E., Gul, M., 2019, An integrated best-worst and interval type-2 fuzzy TOPSIS methodology for green supplier selection, Mathematics, 7, 19 pages, doi:10.3390/math7020182.

34. Žižović, M., Pamučar, D., 2019, New model for determining criteria weights: Level based weight assessment (LBWA) model, Decision Making: Applications in Management and Engineering, 2(2), pp. 126-137.

35. Đalić, I., Stević, Ž., Karamasa, C., Puška, A., 2020, Novel integrated fuzzy PIPRECIA-interval rough saw model: Green supplier selection, Decision Making: Applications in Management and Engineering, 3(1), pp. 126-145.

36. Zhang, J., Chang, W., Zhou, S., 2015, An improved MCDM model with cloud TOPSIS method, In: Proceedings of the $27^{\text {th }}$ Chinese Control and Decision Conference, China, pp. 873-878.

37. Wang, J-Q., Lu, P., Zhang, H-Y., Chen X-H., 2014, Method of multi-criteria group decision-making based on cloud aggregation operators with linguistic information, Information Sciences, 274, pp. 177-191.

38. Wang, T-D., Peng, D-H., Shao, X-S., 2016, A cloud TOPSIS method for multiple criteria decision making with interval number, Advances in Computer Science Research, 44, pp. 389-394.

39. Kannan, D., Govindan, K., Rajendran, S., 2015, Fuzzy axiomatic design approach based green supplier selection: A case study from Singapore, Journal of Cleaner Production, 96, pp. 1-15. 